\title{
Protecting The Rationality of Electoral Outcomes: A Challenge to First Amendment Doctrine
}

A central though rarely articulated premise of many election laws and much democratic theory is that electoral outcomes should be rational rather than irrational-that they should reflect the true, reasoned, and informed choice of the people. Unfortunately, as political scientists have shown, people do not always vote rationally. ${ }^{1}$ They often vote on the basis of incomplete information, ${ }^{2}$ or without understanding election issues, ${ }^{3}$ or in response to factors unrelated to the candidates' fitness for office. ${ }^{4}$ Some observers believe that the irrationality that characterizes many voters and many election results is caused by the presence of an excess of money and irrelevant information in the campaign process. ${ }^{5}$ These observers argue that abuses of the electoral process can be cured by legislation restricting the amount of money that can be spent and the kind of information that can be distributed during a campaign. ${ }^{6}$ These restrictions, so their proponents argue, would remove certain incentives of irrational voting, thereby enhancing the rationality of electoral outcomes.

Faced with the reality of irrational voting behavior, courts, acting both independently and in cooperation with legislatures, have in certain contexts attempted to promote rational voting. In the areas of ballot placement, ${ }^{7}$ electioneering, ${ }^{8}$ disclosure, ${ }^{8}$ and fair

${ }^{1}$ See infra notes 2-4, 25, 40-42 and accompanying text.

2 E.g., Verba \& Nie, The Rationality of Political Activity: A Reconsideration, in Controversies in Amrrican Voting Behavior 45, 46-47 (R. Niemi \& H. Weisberg eds. 1976).

3 E.g., A. Campbell, P. Converse, W. Miller \& D. Stokes, The American Voter 186 (1960).

- E.g., RePass, Issue Salience and Party Choice, 65 AM. PoL. Scr. Rev. 389, 400 (1971) (image of presidential candidates most important factor in electoral decision).

- See, e.g., Converse, Public Opinion \& Voting Behavior, in 4 Handbook of Political ScIENCE 75, 113-36 (F. Greenstein \& N. Polsby eds. 1975) (surveying literature on irrational voting).

- See, e.g., id.

7 E.g., McLain v. Meier, 637 F.2d 1159, 1165-69 (8th Cir. 1980).

s.g., Flamm v. Kusper, 384 F. Supp. 1364 (N.D. Ill. 1974), vacated without opinion, 525 F.2d 695 (7th Cir. 1975).

- E.g., Buckley v. Valeo, 424 U.S. 1, 60-84 (1976) (per curiam) (campaign finance disclosure); United States v. Scott, 195 F. Supp. 440 (D.N.D. 1961) (disclosure of source of 
campaign practices, ${ }^{10}$ courts have rendered decisions favorable to rational electoral outcomes, frequently at the expense of complete freedom of speech. ${ }^{11}$ Yet in cases dealing with the volume of information received by voters, principally Buckley $v$. Valeo, ${ }^{12}$ the Supreme Court has struck down statutes by which Congress, ${ }^{13}$ or a state legislature, ${ }^{14}$ has sought to limit the amount of political speech reaching voters.

The Court's decisions in cases such as Buckley have relied on traditional first amendment doctrine and its underlying fear of government regulation of speech. ${ }^{15}$ This comment argues that the Court's traditional interpretation of the first amendment in election law cases merely substitutes for the evil of government abuse the evil of private abuse of the electoral system by individuals with the resources to exploit voter irrationality. In so doing, the Court treats the first amendment as a barrier to legislation aimed, at least in part, at correcting voter irrationality, and, consequently, as a barrier to more rational electoral outcomes. The Court has recently granted certiorari in Democratic Party v. National Conservative Political Action Committee (NCPAC), ${ }^{16}$ in which the District Court for the Eastern District of Pennsylvania relied on Buckley to invalidate a federal statute limiting the amount of money that a political action committee can spend to further the election of presidential candidates who accept public funding. NCPAC presents an ideal opportunity for the Court to incorporate electoral rationality concerns into its first amendment doctrine.

This comment first examines the importance of rational electoral outcomes from the standpoint of democratic theory and notes

campaign literature).

10 E.g., Garrison v. Louisiana, 379 U.S. 64 (1964); State ex rel. Hampel v. Mitten, 227 Wis. 598, 278 N.W. 431 (1938).

11 See infra notes 44-108 and accompanying text.

12424 U.S. 1 (1976).

13 See id. at 58-59 (1976) (invalidating federal law placing a ceiling on candidates' personal expenditures, independent expenditures, and overall campaign expenditures). For a critical discussion of Buckley and its progeny, see infra notes 124-55, 185-98 and accompanying text.

14 See, e.g., Citizens Against Rent Control v. City of Berkeley, 454 U.S. 290, 295-99 (1981) (invalidating ordinance setting ceilings on contributions to committees formed to support or oppose ballot measures); First Nat'l Bank v. Bellotti, 435 U.S. 765, 786-95 (1978) (invalidating state statute prohibiting corporations from spending money to influence voters on ballot measures). For a critical discussion of these cases, see infra notes 156-98 and accompanying text.

${ }^{15}$ See, e.g., Buckley, 424 U.S. at 14-15.

16 578 F. Supp. 797 (E.D. Pa. 1983), cert. granted, 52 U.S.L.W. 3745 (U.S. April 17, 1984). 
the divergence between the way democratic theory assumes voters will behave and the way they actually do behave. Part II surveys judicial decisions relating to the control of the campaign process, and argues that these cases reveal a willingness on the part of some courts to promote electoral rationality, even when that means limiting speech. Part III discusses Buckley v. Valeo and its progeny, and concludes that these cases, in contrast to those discussed in Part II, improperly favor freedom of speech at the expense of electoral rationality. In Part IV, the comment analyzes the Buckley holding in terms of the traditional first amendment balancing of society's interest in free speech against compelling governmental interests, and suggests that the Buckley Court's decision stemmed from its failure to include in its balance the government's interest in rational voting-a factor which has, with the advent of modern, media-dominated political campaigns, become compelling. Finally, the comment proposes that, in resolving conflicts between the protection of speech and electoral rationality under the first amendment, the public's interest in freedom of speech should be balanced against its vital interest in rational electoral outcomes.

\section{The Rationality of Electoral Outcomes}

Our system of government contemplates that electoral outcomes should be rational rather than irrational. ${ }^{17}$ The government of the United States was formed for the purpose of achieving certain benefits for its citizens. ${ }^{18}$ Our best leaders are those with qualities that enable them to guide the nation toward the attainment of those benefits. ${ }^{19}$ The function of elections is to allow citizens to

17 See, e.g., C. Beckrr, Modern Democracy 14 (1941) (an assumption of the theory of democratic government is that "its citizens are rational creatures"); THE FedERALIST No. 49, at 351 (J. Madison) (B. Wright ed. 1961) ("[I]t is the reason, alone, of the public that ought to control and regulate the government. The passions ought to be controlled and regulated by the government."). For further discussion of the assumption that electoral outcomes should be rational, see infra notes 44-108 and accompanying text.

${ }^{18}$ For example, the Declaration of Independence para. 2 (U.S. 1776) states that "Governments are instituted among Men" to secure "Life, Liberty and the pursuit of Happiness." Later in life, Jefferson wrote: "[T] he equal rights of man, and the happiness of every individual, are now acknowledged to be the only legitimate objects of government." Letter from Thomas Jefferson to J.W. Eppes (1814), in The Wisdom of Thomas Jefrerson 27 (E. Boykin ed. 1941).

19 See The Federalist No. 10, supra note 17, at 134 (J. Madison) (the best leaders will be citizens "whose wisdom may best discern the true interest of their country" and who will be "least likely to sacrifice it to temporary or partial considerations"); see also H. MarNe, Popular Government 62-63 (5th ed. 1897) (leaders of successful states will eschew "caprice, wilfullness, loss of self-command, timidity, temerity, inconsistency, indecency, and coarseness."); cf. Buckley v. Valeo, 424 U.S. 1, 15 (1976) ("The identities of those who are elected 
discern and select the best leaders from among the candidates. ${ }^{20}$ This function is fulfilled, therefore, only when electoral outcomes reflect a deliberate, reasoned judgment by voters as to which candidates are best qualified..$^{21}$ The measure of the rationality of electoral outcomes, then, is the extent to which voters elect those whom they accurately judge to be the leaders most likely to steer the nation toward the attainment of its goals. ${ }^{22}$

will inevitably shape the course that we follow as a nation.").

${ }^{20}$ Frequent elections were meant to ensure that the people continuously reassess the quality of their government, THE FrDerasist No. 52, supra note 17 (J. Madison), and the opportunity to reelect an incumbent allows the electorate "to prolong the utility of his talents and virtues." ThE Federanist No. 72, supra note 17, at 463 (A. Hamilton); cf. The Federauist No. 64, supra note 17, at 421 (J. Jay) (although there was some disagreement at the Constitutional Convention of 1787 , the Framers generally believed that elected bodies would be "composed of the most enlightened and respectable citizens"); THE FeDERALIST No. 68, supra note 17, at 442 (A. Hamilton) (the electoral system devised to elect the President "affords a moral certainty, that the office of President will never fall to the lot of any man who is not in an eminent degree endowed with the requisite qualifications."). While the framers thus seemed to believe that the democratic system which they had constructed would ensure that the best qualified candidate would be elected, it is less clear whether they believed that those best qualified to lead would become candidates. De Tocqueville was strongly of the opinion that the truly best qualified people in America eschewed politics entirely. 1 A. De Tocquevinle, Democracy in Americh 135 (1946) (1st ed. Paris 1835). The present comment does not consider the question of whether the most qualified individuals choose to become candidates, but focuses instead on how rational electoral outcomes might be assured regardless of the relative merits of the candidates as a group compared to those who choose not to run.

${ }^{21}$ See Meiklejohn, The First Amendment is an Absolute, 1961 SuP. CT. REv. 245, 255 ("Self-government can exist only insofar as the voters acquire the intelligence, integrity, sensitivity, and generous devotion to the general welfare that, in theory, casting a ballot is assumed to express."); see also A. MeIkrejohn, Free Speech ANd its Relation to SkLpGovernment 25 (1948) (voting decisions should be made wisely); cf. L. TRIBE, American Constitutionar Law $\$ 13-26$, at 798 (1978) (voters must not be divested of the "power to make a reasoned choice among the candidates").

22 The fact that the framers chose an electoral system of government seems to reflect their conviction that such a system could in fact operate rationally. See, e.g., Letter from Thomas Jefferson to J.W. Eppes, supra note 18 (government by the people is the only way to secure fundamental rights); cf. Letter from Abraham Lincoln to Edward Count Piper (Nov. 8, 1861), reprinted in 5 The Collected Works of Abraham Lincoln 17-18 (R. Basler ed. 1953) ("This country, $\mathrm{Sir}$, maintains, and means to maintain, the rights of human nature and the capacity of man for self-government."). This conviction, however, was not uniformly held by the framers. Many delegates to the Constitutional Convention of 1787 opposed popular elections because "[ $t$ ]he people are uninformed and would be misled by a few designing men." J. Madison, Journal of the Frderal Convention 388 (1898) (1st ed. n.p. 1840) (statement of Elbridge Gerry); see also id. at 78 (Roger Sherman concluded that "[t]he people . . . should have as little to do as may be about the government. They want information, and are constantly liable to be misled."), 120 (Charles Pinckney preferred election of the President by state legislature to popular election), 471 (John Mercer warned that voters would make "the worst possible choice" since "[t]he people cannot know and judge of the character of candidates"). Other delegates favored popular election. See, e.g., id. at 386 (Rufus King concluded that "the people at large would choose wisely" in the election of elec- 
Unfortunately, electoral outcomes are often in practice less rational than democratic theory would postulate. A growing body of commentary suggests that voters, and hence electoral outcomes, are to a large extent irrational..$^{23}$

Political scientists have constructed two competing models to explain voting behavior: the "rational" and "irrational" models. Proponents of the rational model believe that voters are capable of the informed, intelligent voting vital to the role assigned them in a democratic system of government, and thus vote on the basis of their views on the issues disputed in a particular election. ${ }^{24}$ Adherents of the irrational model, by contrast, suggest that voters usually lack the ability to make intelligent electoral decisions, and instead vote on the basis of stimuli, such as a candidate's image,$^{25}$ unrelated to the proper functioning of the democratic process. ${ }^{26}$

tors), 433 (John Dickinson "leaned towards an election [of the President] by the people," which he regarded as the best and purest source), 471 (Benjamin Franklin favored popular election since "[i]t is of great consequence that we should not depress the virtue and public spirit of the common people.").

Ultimately, this dispute led the Convention to settle on a compromise structure for the Constitution. Members of the House of Representatives were to be elected directly by the people, U.S. CoNST. art. I, \& 2, Senators were to be elected by the state legislatures, U.S. CoNsT. art. I, $\S 3$, and the President was to be elected in a hybrid fashion, by electors chosen by the people specifically for that purpose, U.S. CoNST. art. II, § 1 .

2s See infra notes 40-43 and accompanying text.

${ }^{24}$ See, e.g., V. KEY, The Responsible ElEctorate 7-8 (1966) (voters basically rational); Converse, Miller, Rusk \& Wolfe, Continuity and Change in American Politics: Parties and Issues in the 1968 Election, 63 AM. PoL. ScI. Rev. 1083, 1095-1101 (1969) (voters in 1968 election "responsible"; Pomper, From Confusion to Clarity: Issues and American Voters, 1956-1968, 66 AM. PoL. Scr. REv. 415, 416 (1972) (voter awareness increased between 1956 and 1964); Schulman \& Pomper, Variability in Electoral Behavior: Longitudinal Perspectives from Causal Modeling, in ConTroversies in American Voting Behavior, supra note 2, at 196, 205 (presidential elections more affected by voters' positions on public policy in 1964 and 1972 than previously).

${ }^{25}$ At least one study has concluded that, while issues are of some importance to many voters, "images of the presidential candidates are ... the most important factor in the electoral decision." RePass, supra note 4, at 400 .

${ }^{26}$ See, e.g., B. Berelson, P. Lazarspeld \& W. McPhez, Voting 309-11 (1954) (workable democratic system does and must include some uninterested voters); A. CAMPBELL, P. Converse, W. Muller \& D. Stokes, supra note 3, at 171-76 (very low proportion of voters had ideological conception of election issues); Stokes, Some Dynamic Elements of Contests for the Presidency, 60 AM. Pol. Scr. Rev. 19, 25 (1966) (voters are influenced by candidates' personalities as they are portrayed in the media). See generally ConTroversies in AMrrican Voting Behavior (R. Niemi \& H. Weisberg eds. 1976) (presenting an overview of the debate among political scientists as to voter rationality). A largely unexamined but generally accepted assumption of democratic theory is that rational voting is preferable to irrational voting. See supra notes 17-22 and accompanying text. But cf. B. BERELSON, P. LAZARSFELD \& W. McPheE, supra, at 314-15 (the presence in society of uninterested or incompetent voters makes broad social compromises easier and is thus essential to the preservation of the system). 
A rational vote, as noted above, is a vote for a candidate accurately judged by the voter to be the one most capable of fulfilling national goals as perceived by the voter. ${ }^{27}$ Thus, there are at least two elements in a rational vote: the voter must make a judgment, and that judgment must be accurate. The first element is binary: the voter either makes a judgment as to which candidate is best, or he does not. If the voter makes such a judgment, his vote may or may not be rational depending on whether the second element is met, but if he does not make any judgment at all, his vote is plainly irrational. ${ }^{28}$ The second element, by contrast, is a matter of degree: the greater the degree of accuracy of judgment, the more rational the vote.

Accurate voting, and in particular accurate issue voting, depends on the fulfillment of certain conditions. First, the voter must collect information on which to base his decision. ${ }^{28}$ This information collection, in turn, depends on three factors: accurate, relevant information must be available; ${ }^{30}$ the voter must have the capacity and resources to collect the information; ${ }^{31}$ and the voter must wish to use his resources to collect the information. ${ }^{32}$

27 See supra notes 17-22 and accompanying text.

28 A clear example of a voter making no judgment would be voting by flipping a coin. Perhaps a more common technique, equally void of any element of judgment, is voting by choosing the first listed name on the ballot. See infra note 45 and accompanying text. In general, voting by any random or indifferent decision process amounts to a failure to make a judgment. A voter makes no judgment if he votes for someone under a threat of physical force or under some psychological compulsion, such as hypnotism. The essence of the electoral process is for the voter to choose between candidates in a meaningful way. Once the voter has made a judgment, all that remains to be asked is whether the judgment is accurate. See infra notes 29-39 and accompanying text.

20 See A. Camprell, P. Converse, W. Mimler \& D. Stokes, supra note 3, at 169-70 (citizens need access to the making of public policy); Margolis, From Confusion to Confusion: Issues and the American Voter (1956-1972), 71 AM. PoL. ScI. Rev. 31,42 (1977) (voters must know and care about issues, party positions, and current government policies).

so An "issue voter who is proceeding on misinformation cannot be counted as 'rational" " insofar as his vote does not express "what the voter intended and [is] thus subversive of meaningful dialogue." Converse, Public Opinion and Voting Behavior, in 4 HandBOOK OP PoliTiCAL SCIENCE 75, 121 (F. Greenstein \& N. Polsby eds. 1975); see also V. KEY, supra note 24 , at 7 ("[I]n the large the electorate behaves about as rationally and responsibly as we should expect, given the clarity of the alternatives presented to it and the character of the information available to it.").

31 Collecting information can be sufficiently costly to deter some citizens from voting rationally. See, e.g., A. Downs, An Economic Theory of Dzmocracy 265-70, 274 (1957) (tiny variations in cost can redistribute political power). But cf. ConTrovirRIRs IN AMRRICAN Voting BeHAVIOR, supra note 2, at 27 (suggesting that the cost of collecting information is quite small).

13 See, e.g., A. CAMpbeld, P. Converse, W. Mmler \& D. Stokgs, supra note 3, at 170 (voters needed to be alerted to particular issues and to each issue's importance); Brody \& Page, The Assessment of Policy Voting, in Controversies in Amrrican Voting Behuvior, 
The second condition for accurate voting is that the voter, having collected sufficient accurate information upon which to base his decision, must interpret the information in some sense "properly." The ability to interpret information properly depends on education and cognitive skills, ${ }^{33}$ as well as on motivation. ${ }^{34}$ An accurate vote seemingly must entail analysis of at least two criteria: ${ }^{: 5}$ the candidates' positions on the issues faced by the nation, ${ }^{36}$ and the candidates' character, in the sense of their ability to bring their positions on the issues to fruition and to lead the nation. ${ }^{37}$

Finally, the voter must base his decision on the information he has collected and interpreted to the exclusion of irrelevant stimuli or information. ${ }^{38} \mathrm{~A}$ vote is "irrational"-or at least less than per-

supra note 2, at 221, 231 (voters do not necessarily collect information on issues they consider important); Margolis, supra note 29, at 31 (voters must care about issues).

ss See, e.g., C. Broh, Toward a Theory of Issue Voting passim (1973) (issue voting depends on level of conceptualization); Carmines \& Stimson, The Two Faces of Issue Voting, 74 Am. Pol. ScI. REv. 78, 84-85 (1980) (issue voting presumed to be associated with well educated segment of electorate); Nie \& Andersen, Mass Belief Systems Revisited: Political Change and Attitude Structure, in ConTroversies IN Ambrican Voting Behavior, supra note 2, at 94, 96. The conceptual ability of voters has been the focus of the most intense debate between proponents of the rational and irrational models. Compare A. Campresu, $P$. CoNverse, W. MrulER \& D. STOKES, supra note 3, at 216-65 (voters are generally unable to conceptualize political issues), with V. KEY, supra note 24, at 90-106 (significant portion of voters can and do consider ideological issues).

st Brody \& Page, supra note 32 , at 231.

38 Short-cuts may suffice to allow a voter to avoid making a full examination of the issues and each of the candidates' characters. For example, voters might vote on the recommendation of someone they respect, such as a local newspaper or clergyman. The rationality of such a vote depends on the accuracy of the voter's judgment that the recommendor is a reliable weigher of the issues or of a candidate's leadership ability.

30 See A. Campeell, P. Converse, W. Mrler \& D. Stokes, supra note 3, at 216-65. The key to rational voting lies more in the reasoning process than in the consideration or lack thereof of any particular issues. Characteristics normally thought to be unrelated to a candidate's qualifications for office-e.g., race, see Anderson v. Martin, 375 U.S. 399, 402 (1964) (state may not print candidate's race on' ballot because to do so would improperly put state imprimatur on racially-based voting) - may, under certain circumstances, form the basis for a rational vote. For example, a voter may be acting rationally when he votes solely on the basis of race where the voter believes that minority representation in elected bodies must be increased or that black candidates will do more to advance the interests of black citizens than will white candidates. Such a vote is really an issue-based vote, since the issues of concern to the voter involve race and the voter is simply using the candidate's race as a shorthand for calculating the responsiveness of the candidate to those issues. A vote based on race is irrational when there is no reasoned connection between race and the electoral issues of concern to the voter.

37 See Popkin, Gorman, Phillips \& Smith, Comment: What Have You Done for Me Lately? Toward an Investment Theory of Voting, 70 AM. PoL. Scr. Rev. 779, 793-95 (1976) (discussing importance to voters of candidates' competence).

ss See infra notes 44-76 and accompanying text (discussing ballot placement and electioneering cases). 
fectly rational-when any of the above conditions is unfulfilled. ${ }^{30}$ One of the revolutionary findings of modern political science is the prevalence of irrational voting among the American electorate. ${ }^{40}$ Researchers studying voting behavior have estimated the percentage of the electorate having an ideological conception of political issues to be as low as three and one-half percent..1 This dis-

39 An unresolved controversy in voting theory concerns the role of self-interest in voting decisions. Early democratic theorists stressed the collective nature of democratic self-government, thereby suggesting that a rational voter would base his vote on the broad public interest rather than on his own self-interest. See, e.g., J. LockE, supra note 18, at 64 (members of society authorized to make laws "to no other end but the peace, safety, and public good of the people"); The FeDrRaurst No. 10, supra note 17 (J. Madison) (institutions of republican democracy serve the public good); Thre Frderalist No. 57, supra note 17, at 383 (J. Madison) (aim of government is to pursue "the common good of the society"). Recently, this view has been challenged by political scientists who characterize the voting decision as an economically rational, utility-maximizing choice designed to advance the self-interest of the voter. See, e.g., A. Dowss, supra note 31, passim. But see Meehl, The Selfish Voter Paradox and the Thrown-Away Vote Argument, 71 AM. PoL. Scr. Rev. 11 (1977) (voters unlikely to cast votes out of pure self-interest given minimal chance that their self-interest will prevail in election). If the economic view is correct, then public welfare will be maximized only if private interest coincides with public welfare, or if some "invisible hand" operates in the political arena, as it is said to do in the economic arena, to achieve the greatest social good when individuals act out of self-interest. See ConTroversizs in AMrrican VotING BeHAyor, supra note 2, at 23 ("political system might work best when each individual acts primarily in his or her own interest"). For purposes of this comment, voting based on voters' conceptions of the public welfare and voting based on voters' self-interest that happens to promote the public welfare will be considered rational. Self-interested voting that does not promote the public welfare will be considered irrational for purposes of this comment and democratic theory. See supra notes 17-22 and accompanying text. A full analysis of the merits of such voting is outside the scope of this comment.

40 See, e.g., A. CAMpresl, P. Converse, W. Minrer \& D. Stokes, supra note 3 passim.

11 One study found that only $3.5 \%$ of voters in the 1956 presidential election had an ideological conception of political issues, that $17 \%$ lacked any understanding of relevant issues or ideology, and that the rest fell somewhere in between. Id. at 229, 237. Another survey using a similar classification system categorized $13 \%$ of voters in the 1956 presidential election as "ideologues" or "near ideologues," and $87 \%$ as "non-ideologues." See Miller \& Miller, Ideology in the 1972 Election: Myth or Reality-A Rejoinder, 70 AM. PoL. Scr. REv. 832, 844 (1976). In the 1972 election, the most ideologically oriented election in recent years, $i d$. at 846 , the proportion of ideologues and near ideologues rose only to $37 \%$, id. at 844. Other studies using slightly different measures of ideological conceptualization have estimated the proportion of ideological voters as ranging from $13 \%$ in the 1956 election, Pierce, Party Identification and the Changing Role of Ideology in American Politics, 14 Mrdwest J. PoL. ScI. 25, 35 (1970), to 35\% percent in the 1964 election, Field \& Anderson, Ideology in the Public's Conceptualization of the 1964 Election, 33 PuB. OrInIon Q. 380, 388 (1969); see also Margolis, supra note 29, at 38 (1 vote in 20 based on issues in 1964 election). Thus, even the most optimistic of empirical studies find at least two-thirds of the voting public lacking an ideological understanding of electoral issues. For a methodological criticism of these studies, see Smith, The Levels of Conceptualization: False Measures of Ideological Sophistication, 74 AM. PoL. Scr. Ruv. 685 (1980) (criticizing as unreliable the measures of ideological conceptualization used by researchers, and suggesting that actual levels are higher). But cf. Margolis, supra note 29, passim (reviewing studies of issue voting and concluding that its incidence is lower than most studies indicate). 
covery has profound implications for the democratic process. The widespread lack of understanding of electoral issues means that many voters vote without due regard for the central questions disputed in elections, ${ }^{42}$ and that many of those who attempt to formulate judgments concerning electoral issues do so inaccurately. This inaccuracy in electoral decision-making makes it less likely that voters will elect the best qualified candidates. Instead, irrational voting raises the possibility of electing candidates who are, at best, less capable than other contenders, or, at worst, incompetent, unscrupulous, or corrupt. To this extent, irrational electoral outcomes, and the irrational voting that causes them, threaten the proper functioning, and ultimately, the survival of the democratic state. ${ }^{43}$

\section{Decisions Promoting Rational Electoral Outcomes}

The divergence between the theory and reality of voting behavior has confronted courts on numerous occasions. While courts have not recognized or labeled their analyses as attempts to promote rational voting, many of their decisions can be so characterized. In addressing the problems created by irrational voting, courts have implicitly demonstrated a commitment to electoral rationality by taking steps, or permitting steps to be taken, to curb irrational voting. Moreover, where the steps necessary to curb irrational voting conflict with first amendment rights, courts have sometimes treated the interest in rational electoral outcomes as sufficiently strong to justify restraints on freedom of speech.

\section{A. Irrationality at the Polling Place: Ballot Placement and Electioneering}

1. Ballot placement. Ballot placement refers to the order in which the names of candidates appear on an electoral ballot. ${ }^{44}$

42 According to one study, the factor which most frequently explains voting preferences is candidate image. RePass, supra note 4 , at 400.

4s See The Federalist No. 6, supra note 17, at 109 (A. Hamilton):

[Some causes of war] take their origins entirely in private passions; in the attachments, enmities, interests, hopes, and fears of leading individuals in the communities of which they are members. Men of this class, whether the favorites of a king or of a people, . . . have not scrupled to sacrifice the national tranquility to personal advantage or personal gratification.

11 Votes cast on the basis of ballot placement alone are irrational because they ignore the candidates' qualifications, record, positions on the issues, and other factors necessary for an informed, rational vote. See supra notes 35-37 and accompanying text. Ballot placement is not to be confused with ballot access, which refers to the ability of a candidate to get his 
Courts, finding that the first-listed candidate has an advantage over his opponents simply by virtue of being the first name on the ballot, ${ }^{45}$ have struck down statutes that systematically awarded the first ballot position to a particular group or individual. ${ }^{16}$ In $\mathrm{Mc}$ Lain $v$. Meier, ${ }^{47}$ a typical ballot placement case, an unsuccessful candidate challenged a North Dakota statute that reserved the first ballot position for the candidate of the incumbent party, on the grounds that the challenger's supporters were denied the equal protection of their fundamental right to vote, a right guaranteed by the fourteenth and fifteenth amendments. ${ }^{48}$ Accepting the lower

name listed on the ballot at all. For a case discussing the latter, see Williams v. Rhodes, 393 U.S. 23 (1968).

6s See, e.g., McLain v. Meier, 637 F.2d 1159, 1166 (8th Cir. 1980); Bloomenthal v. Lavelle, 614 F.2d 1139, 1141-42 (7th Cir. 1980); Sangmeister v. Woodard, 565 F.2d 460, 465-66 (7th Cir. 1977), cert. denied, 425 U.S. 939 (1978); Weisberg v. Powell, 417 F.2d 388, 392-93 (7th Cir. 1969).

4s See, e.g., McLain v. Meier, 637 F.2d at 1165-67 (8th Cir. 1980) (first position to incumbent party); Sangmeister v. Woodard, 565 F.2d 460, 465-67 (7th Cir. 1977) (first position to party of county clerk), cert. denied, 425 U.S. 939 (1978); Weisberg v. Powell, 417 F.2d 388, 392-94 (7th Cir. 1969) (ballot placement in order of receipt of candidacy application, but state official manipulated order of receipt); Gould v. Grubb, 14 Cal. 3d 661, 669-76, 122 Cal. Rptr. 377, 382-87, 536 P.2d 1337, 1342-47 (1975) (incumbent first, remaining candidates alphebetical order); Holtzman v. Power, 62 Misc. 2d 1020, 1022-25, 313 N.Y.S.2d 904, 907-09 (Sup. Ct.), aff'd., 27 N.Y.2d 628, 261 N.E.2d 666 (1970); see also Annot., 59 L.Ed. 2d 852, 887-891 (1980) (discussing ballot placement cases). But see Clough v. Guzzi, 416 F. Supp. 1057, 1062-66 (D. Mass. 1976) (acknowledging effect of top position but finding legitimate purpose in giving advantage to incumbent).

47637 F.2d 1159 (8th Cir. 1980).

48 Id. at 1166; see San Antonio Indep. School Dist. v. Rodriguez, 411 U.S. I, 59 n.2 (1973) (Stewart, J. concurring) (voters have "the substantive right to participate on an equal basis with other voters"). The United States Constitution does not establish a right to vote in state elections. Id. at $35 \mathrm{n} .78$. Once a state adopts an electoral system, however, the equal protection clause of the fourteenth amendment confers upon qualified voters a right to an "equally effective voice" in that system. Reynolds v. Sims, 377 U.S. 533, 565 (1964); see also Harris v. McRae, 448 U.S. 297, 322 n.25 (1980) (voter has "substantive right to participate in the electoral process equally with other qualified voters"); Hadley v. Junior College Dist., 397 U.S. 50, 55 (1970) (voters have right "to participate on an equal footing in the electoral process"). This guarantee applies to all "procedures used by a State as an integral part of the election process." Moore v. Ogilvie, 394 U.S. 814, 818 (1969). Thus, challengers of state ballot systems usually allege a burden on the right to vote of supporters of candidates disadvantaged by the system. See, e.g., McLain, 637 F.2d at 1159; Clough v. Guzzi, 416 F. Supp. 1057, 1066 (D. Mass. 1976); Gould v. Grubb, 14 Cal. 3d 661, 670-72, 122 Cal. Rptr. 377, 38384, 536 P.2d 1337, 1343-44 (1975).

A right of candidates to run for office might seem a more suitable vehicle for such challenges, but the existence of such a right is rarely suggested. Jardine, Ballot Access Rights: The Constitutional Status of the Right to Run for Office, 1974 UTAH L. RBv. 290, 302-17. The right to vote has been held fundamental, Harper v. Virginia Bd. of Elections, 383 U.S. 663,670 (1966), but the right to run for office has not been similarily elevated. But see Shakman v. Democratic Org. 435 F.2d 267, 270 (7th Cir. 1970) (suggesting that voters' right to effective voice is parallelled by candidates' constitutional right to an "equal chance" in the electoral process); Kautenburger v. Jackson, 85 Ariz. 128, 130-31 333 P.2d 293, 294-95 
court's finding that a significant statistical advantage accrued to the first-listed candidate, ${ }^{49}$ the court of appeals held that the state had no rational basis for allocating to an incumbent the advantages of preferential ballot placement. ${ }^{50}$ Therefore, the court invalidated the statute. ${ }^{.1}$

Courts that have decided ballot placement cases have rested their holdings squarely on the fourteenth amendment and not on considerations of the rationality of electoral outcomes. ${ }^{52}$ The result of these cases, however, is to minimize the effects of irrational voting on electoral outcomes by denying to any single candidate an exclusive windfall ${ }^{53}$ of irrational votes. A fair scheme of ballot placement does not increase the rationality of any particular voter's vote; voters are still free to vote for the first-listed candidate. ${ }^{54}$ Nonetheless, a random distribution of irrational votes does enhance the rationality of the outcome of the election by depriving certain candidates of the systematic benefits of irrationality. ${ }^{.5}$

(1958) ("The right to become a candidate for public office is . . a a fundamental right . . .") (quoting Fisher v. Taylor, 210 Ark. 380, 387, 196 S.W.2d 217, 220 (1946)). Therefore, ballot placement challengers are on sounder fourteenth amendment footing when they argue that the casting of unconcerned votes for the favorably placed candidate dilutes the value of votes cast rationally for other candidates, than they are when arguing that the unfavorably placed candidate has himself been denied equal protection. See Note, Protecting the Polls From the Pols: Federal Prosecution of State and Local Election Fraud, 51 N.Y.U. L. REv. 660, 671-672 (1976); cf. Reynolds v. Sims, 377 U.S. 533, 568 (1964) (legislative apportionments that dilute the value of some voters' votes violate the equal protection clause of the fourteenth amendment). The convoluted logic by which the courts manage to fit ballot placement cases into an equal protection framework suggests less a reasoned extension of equal protection doctrine than a device by which courts correct what they perceive to be a serious wrong.

19637 F.2d at 1163.

so Id. at 1165 .

${ }^{81} I d$.

s2 See, e.g., McLain, 637 F.2d at 1165-67; Sangmeister v. Woodard, 565 F.2d 460, 465-67 (7th Cir. 1977), cert. denied, 425 U.S. 939 (1978); Weisberg v. Powell, 417 F.2d 388, 392-94 (7th Cir. 1969).

5s The fact that such a windfall may be small has not deterred courts from attempting to eliminate it. In McLain, the court specifically noted that a United States Senate seat in North Dakota was won in 1974 by a margin of only 186 votes out of 235,661 votes cast; thus, even a small gain of irrational votes could quite possibly change the result of an election. McLain, 637 F.2d at 1166 n.13.

s4 Compare the electioneering cases, see infra notes 57-76 and accompanying text, the disclosure cases, see infra notes 77-103 and accompanying text, and the false campaignspeech cases, see infra notes 104-08 and accompanying text, where, this comment argues, the courts do attempt to minimize the amount of irrational voting itself.

ss Different methods distribute irrational votes to different degrees. The fairest, though most costly, ballot placement scheme is one allowing all candidates to appear in the top position on some ballots. See, e.g., McLain, 637 F.2d at 1169; Clough v. Guzzi, 416 F. Supp. 1057, 1064, 1068 (D. Mass 1976). Determining ballot order by lot may also be acceptable. Compare Gould v. Grubb, 14 Cal. 3d 661, 676, 122 Cal. Rptr. 377, 387, 536 P.2d 1337, 1347 
Some courts, in the midst of equal protection analyses, have obliquely recognized the importance of rational outcomes. For example, one court noted:

A fundamental goal of a democratic society is to attain the free and pure expression of the voters' choice of candidates. To that end, our state and federal Constitutions mandate that the government must, if possible, avoid any feature that might adulterate or, indeed, frustrate, that free and pure choice . . . . In our governmental system, the voters' selection must remain untainted by extraneous artificial advantages imposed by weighted procedures of the election process. ${ }^{58}$

Ballot placement cases suggest a judicial commitment to rational electoral outcomes, but do not force courts to weigh rational electoral outcomes against first amendment rights. The sections which follow show that the interest in electoral rationality can prevail even at the expense of impinging on freedom of speech.

2. Electioneering. Electioneering, forbidden by statute in most states, $^{\mathrm{sz}}$ is the making of last-minute appeals to voters in the vicin-

(1975) (dictum) ("Although a lottery system for determining ballot position may strike some as 'whimsical' or 'capricious,' such a system, unlike an 'incumbent first' or 'alphabetical order' scheme, does not continually work a disadvantage upon a fixed class of candidates; all candidates are at least afforded an equal opportunity to obtain the preferential ballot position."), with Clough v. Guzzi, 416 F. Supp. 1057, 1068 (D. Mass. 1976) ("a lottery would, in the end, give only one candidate first priority and would arguably entail an even more arbitrary system than [giving the first ballot position to the incumbent]"). At least two courts have deemed an alphabetical listing unconstitutional. See Kautenburger v. Jackson, 85 Ariz. 128, 130-31, 333 P.2d 293, 294-95 (1958); Gould v. Grubb, 14 Cal. 3d 661, 674-75, 122 Cal. Rptr. 377, 386-87, 536 P.2d 1337, 1346-47 (1975).

* Gould v. Grubb, 14 Cal. 3d 661, 677, 536 P.2d 1337, 1348, 122 Cal. Rptr. 377, 388 (1975) (dictum); cf. Canon v. Justice Court, 61 Cal. 2d 446, 453, 39 Cal. Rptr. 228, 232, 393 P.2d 428, 432 (1964) (the "primary concern" of a disclosure statute is the harm "suffered by all the people when, as a result of the public having been misinformed and misled, the election is not the expression of the true public will."); State ex rel. Hampel v. Mitten, 227 Wis. 598, 607, 278 N.W. 431, 435 (1938) ("Nothing is more important in a democracy than the accurate recording of the untrammeled will of the electorate. Gravest danger to the state is present where this will does not find proper expression due to the fact that electors are corrupted or are misled.").

${ }^{67}$ See Alaska Stat. § 15.56.020(a) (1982); ARK. Stat. Ann. § 3-1104(k) (1976) (Supp. 1981); Caz. Elezc. Cods $\$ 29470$ (West 1977); Colo. Rev. Stat. $\$ 1-13-714$ (1980); Conn. Gen. Stat. Ann. § 9-236 (West 1967 \& Supp. 1984); Del. Codr Ann. tit. 15, § 4942 (1981); Fla. Stat. AnN. \& 104.36 (West 1982); Ga. Code AnN. \& 21-2-414 (1982); HawaI Rev. Stat. \$ 11-132 (1976 \& Supp. 1983); IND. Code § 3-1-32-40 (1982); Iowa Code ANN. § 49.107(1) (West 1973 \& Supp. 1984); Kan. Stat. Ann. \& 25-2430 (1981); Ky. Rev. Stat. § 117.235 (1982); La. Rzv. Stat. ANn. \& 18:1462 (West 1979 \& Supp. 1984); Mz. Rev. Stat. ANn. tit. 21, § 892 (1983); Mass. AnN. Laws ch. 51, § 52A (Michie/Law. Co-op 1978); MinN. STAт. \$ 210A.11 (1962); Miss. Codz ANn. § 23-3-17 (1972 \& Supp. 1983); Mo. Rev. Stat. § 115.637(18) (1980); Mont. Code ANN. § 13-35-211 (1983); NkB. REv. StAT. § 32-1221 (1978); 


\section{ity of the polling place. The paradigm of forbidden electioneering}

Nev. Rev. Stat. § 293.592 (1979); N.J. Rev. Stat. § 19:34-15 (1964); N.M. Stat. ANn. § 1-2016 (1978); N.Y. El.rc. LAW § 8-104 (McKinney 1978); N.C. GEN. STAT. § 163-147 (1982); N.D. Cent. Code § 16.1-10-06 (1981); Ohio Rev. Code AnN. § 3501.35 (Page 1972); OkLA. Stat. AnN. tit. 26, § 16-111 (West 1976); OR. Rev. Stat. § 260.695(2) (1981); PA. Stat. AnN. tit. 25, § 3060(c) (Purdon 1963); R.I. Gen. Laws § 17-19-49 (1981); S.C. Code ANn. § 7-25-180 (Law. Co-op 1977); Tenn. Code Ann. \& 2-7-111 (1979 \& Supp. 1983); Tex. Rev. Crv. Stat. Ann. art. 8.27 (Vernon 1967 \& Supp. 1984); UtAf Code ANN. § 20-13-17 (1976); VA. Code § 24.1101 (1980); Wash. Rev. Code ANn. § 29.51-020 (1965); W. VA. Code § 3-9-9 (1979); Wis. Stat. ANN. § 12.64 (West 1967); Wyo. Stat. § 22-26-113 (1977). Electioneering might also fall within the prohibitions of D.C. CoDE ANN. § 1-1318(b)(3)(c) (1981 \& Supp. 1983), and IDAHO CODE $\S 34-1105$ (1981). Where the electoral will has been thwarted by election irregularities, the offending candidate, if successful, may be removed from office under state laws. At common law, the entitlement of an office-holder to his office could be tested by an action in the nature of quo warranto. State ex rel. Lilienthal v. Herndon, $23 \mathrm{Fla} .287,2$ So. 4 (1887); State ex rel. Barton v. Frantz, 55 Neb. 167, 75 N.W. 546 (1898); Gates v. Hays, 95 S.W.2d 1020 (Tex. Civ. App. 1936). In most states, the quo warranto action has been supplemented or replaced by a statutory scheme for contesting elections under which an election is voidable for fraud or irregularities. See AlaSka Stat. \& 15.56.110 (1982); ARK. Stat. AnN. § 3-1007 (1976) (Supp. 1981); Cal. Elec. Code § 20111 (West 1977); Colo. Rev. Stat. § 1-11201 (1980); Conn. Gen. Stat. Ann. \$§ 9-323 to 9-328 (West 1967 \& Supp. 1984); Dei.. Code ANN. tit. 15, §§ 5906, 5943 (1981); D.C. Code ANN. § 1-1315 (b) (1981) (Supp. 1983); FlA. Stat. ANN. \$ 102.168 (West 1982); GA. Code ANN. § 21-2-527 (1982) (Supp. 1983); HawaII Rev. StaT. § 11-174.5 (b) (1976) (Supp. 1983); IDaho Code §§ 34-2024, 34-2104 (1981); IrL. Ann. Star. ch. 46, \& 23-29 (Smith-Hurd 1965 \& Supp. 1983); Ind. Code ANn. § 3-1-28-5 (West 1982); Iowa Code Ann. §§ 58.7, 59.6, 60.6 (West 1973 \& Supp. 1984); Kan. Stat. AnN. § 25-1448 (1981); Ky. Rev. Stat. § 120.015 (1982); LA. Rev. Stat. ANn. § 18:1432 (West 1979 \& Supp. 1984); Me. Rev. Stat. Ann. tit. 21, § 1212 (1983); MD. ANN. Code art. 33, § 19-2 (1982); Minn. Stat. Ann. § 209.07 (West 1962 \& Supp. 1984); Miss. Code Ann. § 23-3-45 (1972 \& Supp. 1983); Mo. Rev. Stat. § 115.593 (1980); Mont. Code AnN. § 13-36-209 (1983); Neb. Rev. Stat. § 32-1001.22 (1978); Nev. Rev. Stat. § 293.417(4) (1981); N.J. Stat. AnN. § 19:29-9 (West 1964); N.D. Cent. Code § 16.1-16-08 (1981); Ono Rev. Code ANN. § 3515.14 (Page 1972); OkLa. Stat. Ann. tit. 26, § 8-119 (West 1976); Or. Rev. Stat. § 258.065 (1981); Pa. Stat Ann. tit. 25, §§ 3329, 3405 (Purdon 1963); S.C. Code ANn. § 7-1-50 (Law. Co-op 1977); Tenn. Code Ann. \$ 2-17-112 (1979); Tex. Rev. Crv. Star. Ann. art. 9.15 (Vernon 1967); UTAH CODE ANN. \& 20-15-10 (1976); VA. Code § 24.1-236 to 24.1-240 (1980); Wash. Rev. Code ANN. § 29.65 .020 (1965); W. VA. Code §§ 3-7-2, 3-7-7 (1979); Wis. Stat. ANn. § 13.23 (West 1967 \& Supp. 1983); Wyo. Stat. \& 22-17-108 (1977). Compare In re Hart, 159 N.Y. 278, 285, 54 N.E. 44, 45-46 (1899) (quo warranto is only proceeding available to oust office-holder), with State ex rel. Barton v. Frantz, 55 Neb. 167, 170, 75 N.W. 546, 547 (1898) (quo warranto and statutory contest are alternative remedies). While most such statutes provide for election contests to be decided by courts, some states reserve decisions in contests for certain offices for the legislature. E.g., IDAHo CoDE \$§ 34-2024, 34-2104 (1981); IOWA Code Ann. §§ 58.7, 59.6, 60.6 (West 1973 \& Supp. 1984); Pa. Stat. AnN. tit. 25, §§ 3329, 3405, (Purdon 1963); W. VA. Code §§ 3-7-2, 3-7-7 (1979); Wis. Stat. ANN. § 13.23 (West 1967 \& Supp. 1983). In other states, the sole remedy is administrative. E.g., S.C. CoDE ANN. \$ 7-17-30 (Law. Co-op 1977). An election is typically set aside through the disqualification of illegal or fraudulent votes, followed by a recount of the remaining legitimate ballots. E.g., Ralston v. Scott, 354 Ill. 258, 261, 188 N.E. 480, 481 (1934); Hanson v. Emanuel, 210 Minn. 271, 272, 297 N.W. 749, 751 (1941); Dilsaver v. Pollard, 191 Neb. 241, 242, 214 N.W.2d 478, 480 (1974); Otworth v. Bays, 155 Ohio St. 366, 369, 98 N.E.2d 812, 814 (1951).

Courts are understandably reluctant to set aside an election, and generally will do so only in extreme cases. E.g., Davis v. Los Angeles County, 12 Cal. 2d 412, 427, 84 P.2d 1034, 
is outright coercion and intimidation of voters, ${ }^{68}$ behavior which, if successful, plainly reduces the rationality of voting. ${ }^{59}$ Electioneering need not, however, involve outright physical coercion. State courts have found electioneering violations where a candidate campaigned politely at the polling place, ${ }^{60}$ and where a statement

1042 (1938) (" $[\mathrm{A}] \mathrm{n}$ election will not be declared a nullity if upon any reasonable basis such a result can be avoided."); Kirchoff v. Humboldt Community School Dist., 253 Iowa 756, 760, 113 N.W.2d 706, 709 (1962) ("[A]fter an election has been held and the voters have spoken, such election will not be held invalid . . . in the absence of fraud, prejudice or definite legislative pronouncement thereon."); see also Armantrout v. Bohon, 349 Mo. 667, 672, 162 S.W.2d 867, 871 (1942) ("elections are not lightly set aside"); In re Foy's Election, $228 \mathrm{~Pa}$. 14, 19, 76 A. 713, 715 (1910) ("A court ought always to be slow to set aside an election . . .."). But see Carter v. Lambert, $288 \mathrm{Ky} .39,41-42,155$ S.W.2d 38, 40 (1941) ("[T]he bribery of one vote is sufficient to void the nomination of a successful candidate."). Accordingly, in most states, elections will not be set aside despite election offenses and illegal voting unless the corruption influenced a sufficient number of votes to affect the outcome. Some states have enacted this rule expressly through legislation, see, e.g., DrL. Codr ANN. tit. 15, § 5943 (1981); GA. CODE ANN. § 21-2-527 (c) (1982) (Supp. 1983); IDAHo CoDE § 342103 (1981); Iowa Cods AnN. § 57.4 (West Supp. 1984); Kan. Stat. ANn. § 25-1436 (b)-(d) (1981); La. Rev. Stat. ANN. \& 18:1432 (West 1979 \& Supp. 1984); Wash. Rev. Code AnN. § 29.65.100 (1965); in others, the rule has evolved judicially, see, e.g., Williams v. Venneman, 42 Cal. App. 2d 618, 621, 109 P.2d 757, 759 (1941); Suttle v. Sullivan, 131 Colo. 519, 525-26, 283 P.2d 636, 637 (1955); Pyron v. Joiner, 381 So.2d 627, 630 (Miss. 1980); Otworth v. Bays, 155 Ohio St. 366, 370-71, 98 N.E.2d 812, 814-15 (1951); Emery v. Robertson County Election Comm'n, 586 S.W.2d 103, 109 (Tenn. 1979). Instances of courts invalidating elections are rare, but by no means unknown. E.g., Boucher v. Bomhoff, 495 P.2d 77, 83 (Alaska 1972); Williams v. Venneman, 42 Cal. App. 2d 618, 621, 109 P.2d 757, 759 (1941); Carter v. Lambert, 288 Ky. 39, 42, 155 S.W.2d 38, 40 (1941); Otworth v. Bays, 155 Ohio St. 366, 371, 98 N.E.2d 812, 814-15 (1951); In re Foy's Election, 228 Pa. 14, 19-20, 76 A. 713, 716 (1910); Emery v. Robertson County Election Comm'n, 586 S.W.2d 103, 110 (Tenn. 1979).

The invalidation of elections is only one of the major avenues to cleaning up elections, the other being punishment of those who break election laws. Obviously, this is a ubiquitous solution, and the felony conviction of an official, whether or not election-related, can constitute grounds for removal from office. See, e.g., D.C. Cons ANN. § 1-1304(d)(1) (1981 \& Supp. 1983).

* Cf. Lewis v. Democratic Executive Comm., 95 So. 2d 292, 297 (La. 1957) (court declined to annul an election where the plaintiff alleged that a certain policeman had snatched voting cards out of some voters hands, returning them with another name on them). Coercion, intimidation, and bribery of voters have a venerable history in both the United States and England. In American cities around the turn of the century, "elections were riotous affairs in which brawls, bribery and intimidation of voters were common practices." Callow, Vote Early and Often, in The City Boss IN America 158, 158 (A. Callow ed. 1976). For an account of a much earlier outbreak of electoral corruption, see Morgan, An EighteenthCentury Election in England, 37 PoL Scr. Q. 585, 593-95 (1922) (describing English parliamentary elections of 1710). See also Baum v. State, 61 N.E. 672, 673-74 (Ind. 1901) (discussing the common law penalties for electoral crimes).

so Votes cast as a result of intimidation may be prudent but are not "rational" as this comment defines that word, see supra note 28 and accompanying text, and will not generally be counted in the election returns, see supra note 57.

so E.g., Fish v. Redeker, 2 Ariz. App. 602, 604, 411 P.2d 40 (1966). The Fish court held that the gravamen of the electioneering offense consisted of a candidate "trying to get his name before the voters in a last chance effort to influence the votes." Id. at 605, 411 P.2d at 
printed on the ballot to explain a complex ballot issue was suggestively worded. ${ }^{61}$ An even more expansive view of electioneering appears in the federal case of Flamm $v$. Kusper. ${ }^{62}$ There, a county clerk who was running for re-election, acting in his capacity as clerk and as required by law, ${ }^{63}$ posted in polling places announcements containing voting information but also displaying his own name and office in prominent letters. ${ }^{64}$ The court held that this method of publicity constituted electioneering, because last-minute exposure to the name of the defendant "may very well influence some uncommitted voters to vote for" the incumbent."

In addition to raising a challenge based on the Illinois fair election statute, ${ }^{\mathbf{6}}$ the plaintiff in Flamm raised an equal protection claim. After noting that a case involving "the right of a candidate for public office to have equal protection or equal treatment" raises a federal question under the Constitution, ${ }^{67}$ the court concluded that the frequent repetition of the incumbent's name in the polling place gave him an unfair advantage over his opponent, the plaintiff, and violated her right to equal protection of the laws. ${ }^{68}$ The

43. The court based its decision on statutory grounds and did not consider any fourteenth amendment claims. See also Ciempa v. Comfort, 507 F.2d 3 (1st Cir. 1974) ("greeting by speaking . . . may be thought a mild form of electioneering"). With these cases compare Coray v. Aeilyoshi, 54 Hawaii 254, 506 P.2d 13 (1973) (standing outside limit of 1000 feet and recording names of voters not electioneering). See also People v. Ellis, 74 Ill. 2d 489, 384 N.E.2d 331 (1978) (pollwatcher who gave Republicans democratic ballots and told people whom to vote for when they asked for assistance held to be electioneering).

61 Gormley v. Lan, 181 N.J. Super. 7, 13-14, 436 A.2d 535, 538-39 (1981) (successful challenge to an "interpretative statement" written by the Attorney General and required by law to be put on the ballot, where the referendum concerned the right of the state to claim tidal laws and the statement began "Land now formerly flowed by the tide belongs to the people of this state," which statement the court held to be "misleading" as to the law), aff'd, 88 N.J. 26, 438 A.2d 519 (1981); Guernsey v. Allan, 63 N.J. Super. 270, 278, 164 A.2d 496, 500 (1960) (successful challenge to an interpretative statement, an otherwise permissible accompaniment to a ballot question under pertinent municipal law, which stated that the proposed plan of borough government would be "modern" and involve a "qualified" manager); see also Boucher v. Bomhoff, 495 P.2d 77, 81 (Alaska 1972) (results of referendum set aside due to misleading language). Biased interpretive statements amount to electioneering because they attempt to influence voting within the polling place. See Guernsey v. Allan, 63 N. J. Super. 270, 275, 164 A.2d 496, 499 (1960) ("[The state] may not, through the medium of an allegedly 'interpretative' statement, invade the polling place and enter the election booth to urge the voter to cast his vote for its cause . . . .").

62384 F. Supp. 1364 (N.D. Ill. 1974), vacated on other grounds, 525 F.2d 695 (7th Cir. 1975).

is Id. at 1365 .

Id. at 1365-66

${ }^{65} I d$. at 1367.

68 ILl. Rev. Stat. ch. $46, \S 17-29$ (1983).

384 F. Supp. at 1366.

es Id. 
court did not consider any first amendment claims of the incumbent, nor did it expressly acknowledge the goal of rational electoral outcomes in its decision.

The type of electioneering prohibited in Flamm presents a clear threat to the rationality of electoral outcomes. The possibility that some suggestible voters might vote for the candidate whose name they have most recently seen or heard raises the specter of an election won not by the candidate most qualified, but by the one most conspicuous at the polls. ${ }^{68}$

This comment argues that electioneering decisions would be better reasoned if they relied on the protection of the rationality of electoral outcomes. Moreover, though the court in Flamm made no mention of first amendment concerns, without a commitment to rational voting in the background, electioneering cases are difficult to explain in light of possible first amendment challenges to these statutes. Electioneering is a form of speech, and any regulation or prohibition of it necessarily implicates the first amendment. ${ }^{\text {.0 }}$

At least one court has characterized electioneering statutes as permissible restrictions on the time, place, and manner of campaign speech, ${ }^{71}$ justifying the restriction on the basis that the presence of campaigners at the polling place interferes with the orderly process of voting. ${ }^{72}$ The time, place, and manner rationale does not, however, justify restrictions on the type of electioneering prohibited in Flamm. A poster, button, or sticker does not interfere with the administration of voting to any significant extent. Even if these items have a disruptive potential, state regulation of the

os The presence may be visual or aural. Some electioneering statutes ban the wearing of buttons or posting of signs in the vicinity of the polling place. E.g., Mich. CoMP. LAws ANN. $\S 168.744$ (West 1967 \& Supp. 1983) (stickers); N.Y. ElEc. LAW $\$$ 8-104 (McKinney 1978) (banners, buttons, posters, and placards).

${ }^{70}$ The Supreme Court, in the context of a libel suit brought by a senatorial candidate against a reporter who characterized him as a "bootlegger," has stated that the consititutional guarantee of freedom of speech "has its fullest and most urgent application precisely to the conduct of campaigns for political office." Monitor Patriot Co. v. Roy, 401 U.S. 265, 272 (1971).

7 Turner v. Cooper, No. 83-C1167, slip op. (N.D. Ill. Nov. 1, 1983) (upholding a complaint alleging the unconstitutionality of electioneering statutes against motion to dismiss, but finding that the Hllinois law restricting physical closeness of the pollwatcher was a valid time, place, and manner restriction); cf. Grayned v. City of Rockford, 408 U.S. 104 (1972) (upholding an ordinance prohibiting noise or diversions which disturb the peace and order of schools).

72 The operative test for time, place, and manner restrictions is "whether the manner of expression is basically incompatible with the normal activity of a particular place at a particular time." Grayned v. City of Rockford, 408 U.S. 104, 116 (1972). 
items themselves ${ }^{73}$ would more effectively accomodate the first amendment interest of individuals in presenting voters with political speech than does an outright ban. ${ }^{74}$ Furthermore, a valid time, place, and manner restriction based on the government's interest in orderly voting would not single out campaign speech for restraint; the presence in the polling place of people speaking on other subjects would be equally disruptive. ${ }^{75}$

This comment proposes that electioneering cases such as Flamm can be best understood as resting on the implicit recognition of a government interest in rational voting. Indeed, restrictions on electioneering are more closely tailored to protect this interest than they are to protect any interest in orderly voting. The first amendment balance ${ }^{76}$ is tipped in favor of a ban on speech by

7s The state could, for instance, regulate the size or display of posters or set aside one area where each candidate listed on the ballot could put up one poster of a certain size, color, or typography. Cf. Metromedia, Inc. v. City of San Diego, 453 U.S. 490 (1981) (upholding ordinance regulating billboards for aesthetic reasons).

${ }^{74}$ E.g., Gooding v. Wilson, 405 U.S. 518, 528 (1972) (statute so broad as to accommodate improper application); Landmark Communications, Inc. v. Virginia, 435 U.S. 829, 84142 (1978) (state interest in preserving the reputation of judges insufficient to justify statute regulating speech). Even if the government can demonstrate a compelling interest in regulating speech, the first amendment generally permits only as much suppression of speech as is necessary to protect that interest.

${ }^{70}$ The time, place, and manner doctrine is usually invoked to justify content-neutral restrictions on speech, i.e. restrictions that apply to all speech regardless of its topic. The fact that electioneering statutes single out for restriction a particular subject-campaign speech-suggests that such statutes may be facially invalid. See Police Dep't v. Mosley, 408 U.S. 92, 101-02 (1972) (striking down an ordinance prohibiting all picketing except labor picketing near schools while classes are in session). Professor Stone has argued that less stringent treatment should be accorded restrictions that, though biased as to content, are neutral as to the speaker's viewpoint. Stone, Restrictions of Speech Because of its Content: The Peculiar Case of Subject-Matter Restrictions, 46 U. CHI. L. REv. 81, 108-15 (1978).

${ }^{36}$ While the first amendment may appear by its language to be an absolute limit on legislative power, it has not been so construed. E.g., Konigsberg v. State Bar, 366 U.S. 36, 49 (1961) (scope of first amendment protection need not be gathered solely from a literal reading of constitutional language). Instead, the rights guaranteed by the first amendment, the rights of freedom of speech and freedom to associate (which promotes and fosters informed speech, see NAACP v. Alabama, 357 U.S. 449, 460-61 (1958) (compelled disclosure of membership lists is likely to constitute an effective restraint on its members' freedom to associate)) must be balanced in each case against the governmental interest supporting the governmental restriction on speech. E.g., Buckley v. Valeo, 424 U.S. 1 (1976) (applying balancing approach to uphold partially and to strike down partially election regulations). The scrutiny engaged in by courts is exacting, and the asserted interest must be "compelling" and "narrowly drawn" before a restriction is upheld. See, e.g., NAACP v. Alabama, 357 U.S. at 463.

Some kinds of speech, such as commercial speech, see, e.g., Central Hudson Gas \& Elec. Corp. v. New York, 447 U.S. 557, 562-63 (1980), and obscenity, Roth v. United States, 354 U.S. 476, 485 (1957), receive less or no first amendment protection, but political speech has traditionally been held to be one of the "core" types of speech meant to be protected by the first amendment. Monitor Patriot Co. v. Ray, 401 U.S. 265, 272 (1971) (first amendment has 
the governmental interest in protecting voters from outright or subtle influences tending to undermine voting rationality.

\section{B. Statutes Requiring Disclosure of Contributions and Sup- porters}

\section{Disclosure of the Source of Political Contributions. Many} states and the federal government have enacted statutes that require candidates for political office to disclose publicly the sources of contributions to their campaigns. ${ }^{77}$ These laws have been attacked as violating the first amendment, but have been upheld by state courts ${ }^{78}$ and the Supreme Court. ${ }^{79}$ In Buckley v. Valeo, ${ }^{80}$ the Supreme Court considered the constitutionality of the disclosure provisions $^{81}$ of the Federal Election Campaign Act of 1971

fullest application to political campaign speech).

The principal justification for the Court's exacting scrutiny of restrictions on political speech is that in a self-governing society, see Meiklejohn, supra note 21, passim (first amendment aimed at assuring effective self-government), political speech is of critical importance. To a great extent, first amendment doctrine conceives of the electoral arena as a marketplace of political ideas, see Abrams v. United States, 250 U.S. 616, 630 (1919) (Holmes, J., dissenting), in which ideas are advanced, refuted, see Whitney v. California, 274 U.S. 357, 377 (1927) (Brandeis, J., concurring) (remedy for bad or false speech is counterspeech), and discussed by the public in the course of formulating electoral decisions. The very idea of self-government requires that the people be free to discuss and debate political ideas without interference; thus, government may place restrictions on political speech only for the most compelling reasons. This comment argues that the protection of the rationality of electoral outcomes ought to be recognized as one such compelling interest. The first amendment seeks to ban certain governmental interferences with free political speech. But governmental interferences designed to foster rational electoral outcomes serve not to distort the marketplace of political ideas, but rather to correct significant existing marketplace imperfections. These internal market imperfections, due partly to voter irrationality and partly to the maldistribution of resources available for electoral speech, can endanger the democratic political process just as surely as external interferences with political speech. Accordingly, otherwise proper governmental correction of these imperfections should be viewed as an important and permissible regulation of speech.

${ }^{77}$ See Developments in the Law-Elections, 88 HARv. L. REv. 1111, 1241-42 nn.37-39 (1975) (listing statutes for thirty-four states, the District of Columbia, and the United States).

78 See, e.g., Fortson v. Weeks, 232 Ga. 472, 482, 208 S.E.2d 68, 76 (1974) ("It is in the public interest to disclose who is financing political candidates . . . . Such information permits the voters to more intelligently appraise a candidate's true position on public affairs."); cf. Brown v. Superior Court, 5 Cal. 3d 509, 523, 487 P.2d 1224, 1233, 96 Cal. Rptr. 584, 593 (1971) (state disclosure laws which require a greater amount of disclosure for ballot measure elections than for candidate elections held not to violate the equal protection clause and further justified as permitting "informed exercise of the franchise").

70 Buckley v. Valeo, 424 U.S. 1, 66-67 (1976); see Rosenthal, Campaign Financing and the Constitution, 9 HARv. J. ON LEGIS. 359, 403 (1972) (publicity of contributions would deter bribery and corruption).

so 424 U.S. 1 (1976).

s1 2 U.S.C. $\S \S 431-442$ (1982). 
(FECA). ${ }^{82}$ The Court upheld the provisions against the argument that forced disclosure threatened to chill the right to "privacy of association and belief,"83 thereby deterring those who wished to lend anonymous support to a candidate. ${ }^{84}$ The court applied "exacting scrutiny" and required a "substantial relation" between the governmental interest and the information required to be disclosed in order to justify the requirement. ${ }^{85}$ The Court reasoned that important interests were directly served by three aspects of the disclosure requirements: first, disclosure aids voters in evaluating those who seek public office; second, it deters post-election corruption by identifying generous supporters before the election; and third, disclosure assists the government in gathering the data necessary for enforcement of limitations on campaign contributions. ${ }^{\mathbf{s e}}$

Although the Court did not explicitly acknowledge concern for rational electoral outcomes as a legitimate governmental interest, it did use the following language in upholding the disclosure requirements:

[D]isclosure provides the electorate with information "as to where political campaign money comes from and how it is spent by the candidate" in order to aid the voters in evaluating those who seek federal office. It allows voters to place each candidate in the political spectrum more precisely than is often possible solely on the basis of party labels and campaign speeches. The sources of a candidate's financial support also alert the voter to the interests which a candidate is most likely to be responsive and thus facilitate predictions of future performance in office. ${ }^{87}$

Implicit in the Court's argument is an assumption that voters are capable of rationally using contribution information, and that they will use that information to predict more accurately the potential performance in office of the candidates, an effect implicitly assumed by the Court to be beneficial. ${ }^{88}$ By justifying disclosure re-

${ }_{82}$ Pub. L. No. 92-225, 86 Stat. 3 (1971), as amended by Pub. L. No. 93-443, 88 Stat. 1263 (1974) (codified as amended at 2 U.S.C. $\$ \S 431-456$ (1982) and in scattered sections of 18 \& 47 U.S.C. (1982)).

8s 424 U.S. at $48-49$; see infra note 159.

34 424 U.S. at 66 . For an earlier discussion of the first amendment protection of anonymity, see Fortson v. Weeks, 232 Ga. 472, 482, 208 S.E.2d 68, 76 (1974).

${ }^{85} 424$ U.S. at 64 .

${ }^{86}$ Id. at $67-68$.

${ }^{87}$ Id. at 66-67 (quoting H.R. REP. No. 564, 92nd Cong., 1st Sess. 4 (1971)).

ss Debates on the Senate floor prior to adoption of the federal disclosure law suggest a strong congressional belief that some voters-enough to make a difference in election out- 
quirements in this manner, therefore, the Court implicitly acknowledged electoral rationality as a factor to be considered in the balancing of speech protection against legitimate state interests mandated by the first amendment. ${ }^{89}$ The implication of the Court's language is that the promotion of electoral rationality, when combined with other governmental interests, may outweigh the impingement on first amendment rights of free speech and association inherent in certain election laws.

2. Disclosure of the Source of Campaign Literature. Another kind of disclosure law, enacted by most states $^{90}$ and by the federal government, ${ }^{\theta 1}$ requires that political campaign literature identify its author or sponsor. Authorship-identity statutes have been challenged on the ground that they may have a chilling effect on speech because forced disclosure deters the dissemination of views by those who wish to remain anonymous. ${ }^{92}$ Courts have adopted a balancing approach to see "whether the end to be achieved by the disclosure requirement justifies the resulting impairment of freedom of expression." "93 In Canon v. Justice Court, ${ }^{\text {"4 }}$ for example, the California Supreme Court concluded that a provision of the California Elections Code requiring the identification of the source of

comes-would profit from the availability of campaign finance information, thus enhancing the rationality of electoral outcomes. See, e.g., 117 CoNG. REc. 29,322 (1971) (statement of Sen. Talmadge) ("Americans have a sacred obligation to exercise their franchise and to do so in an informed and intelligent manner."); id. at 29,323 (statement of Sen. Symington) ("An informed public must be given 'maximum information' about those who hold public office if they are to have an opportunity to properly evaluate their actions and decisions."); id. at 30,071 (statement of Sen. Mansfield) ("I think it is the unanimous belief of the Senators here today, that a more informed electorate is a better electorate, and that with a better electorate you have an improved government.").

While campaign finance disclosure laws presuppose the existence of a group of rational voters, their effect is not vitiated by the presence of irrational voters. Even as to irrational voters, legislatures might hope that the dissemination of potentially useful information will have a salutary effect by educating them as to proper voting habits. See Letter from Thomas Jefferson to William Charles Jarvis (Sept. 28, 1820), in 10 The Writings of Thomas Jerrerson 161 (P. Ford ed. 1899) ([n]f we think [the people] not enlightened enough to exercise their control with a wholesome discretion, the remedy is not to take it from them, but to inform their discretion .....").

See supra note 88 .

oo See Developments in the Law-Elections, 88 HARv. L. Rkv. 1111, 1287 n.302 (1975) (listing forty-three state statutes requiring disclosure of the identity of the author of campaign literature).

פ2 See 2 U.S.C. § 441(d) (1982).

02 See, e.g., Talley v. California 362 U.S. 60, 64 (1960) ("There can be no doubt that such an identification requirement would tend to restrict freedom to distribute information and thereby freedom of expression.").

's Canon v. Justice Court, 61 Cal. 2d 446, 458, 393 P.2d 428, 433, 39 Cal. Rptr. 228, 233 (1964); United States v. Scott, 195 F. Supp. 440, 443-44 (D.N.D. 1961).

\%4 61 Cal. 2d 446, 393 P.2d 428, 39 Cal. Rptr. 228 (1964). 
campaign material ${ }^{95}$ did not violate the first amendment because "the public interest in more complete information and clean, free elections . . . exceeds the interest in the marginal decrease in freedom of expression resulting from loss of anonymity," the scope of the statute was "tailored to fit its purpose" in that it was "limited to election campaigns, to writings attacking candidates and then only if the attack is primarily personal in nature."97

Laws requiring the disclosure of the source of campaign literature enhance the rationality of electoral outcomes in two ways. ${ }^{98}$ First, knowledge of the identity of the author gives voters the opportunity to discern bias and make an informed judgment as to the weight the literature should be accorded. ${ }^{9}$ Second, statutes banning anonymous campaign literature deter smear campaigns, a potent means of encouraging irrational voting. ${ }^{100}$ Smear campaigns undermine the rationality of electoral outcomes by misleading voters through falsehoods or appeals to bigotry or stereotypes. ${ }^{101} \mathrm{Au}-$

9s Cal. Elec. Code § 12047 (1964).

${ }^{86} 61 \mathrm{Cal} .2 \mathrm{~d}$ at $459-60,393 \mathrm{P} .2 \mathrm{~d}$ at $436,39 \mathrm{Cal}$. Rptr. at 236. Compare Vanasco v. Schwartz, 401 F. Supp. 87, 94 (E.D.N.Y.) (three-judge panel), aff'd, 423 U.S. 1041 (1975), where the court struck down state laws which prohibited "misrepresentation" and "attack on a candidate based on race, sex, religion, or ethnic background." Id. at 88. The court reasoned that it would be a "retreat from reality" to suppose that the public interest in such factors was not great, and held that the state could not legislate the characteristics that were suitable to consider in deciding between candidates. Id. at 94. Even speech that is "offensive" and "provocative," the court stated, is protected by the first amendment so long as it does not fall into the "narrowly limited classes" of unprotected speech, such as fighting words or obscenity. Id.

${ }^{97} 61$ Cal. $2 \mathrm{~d}$ at 459,393 P.2d at 436 , 39 Cal. Rptr. at 236.

s8 Unlike campaign contribution disclosure provisions, laws that ban anonymous campaign literature serve little if any anti-corruption purpose; they perform primarily an informational function.

99 See United States v. Scott, 195 F. Supp. 440, 443-44 (D.N.D. 1961); Canon v. Justice Court, 61 Cal. 2d 446, 459, 393 P.2d 428, 435, 39 Cal. Rptr. 228, 235 (1964).

${ }^{100}$ See, e.g., Canon v. Justice Court, 61 Cal. 2d 446, 452-53, 393 P. 2d 428, 432, 435, 39 Cal. Rptr. 228, 232, 235 (1964); Effertz v. Schimelpfenig, 207 Minn. 324, 329, 291 N.W. 286, 288 (1940) (dictum).

101 Courts have been quite careful in limiting the scope of the legislative controls on smear campaigns. Statutes requiring disclosure of authorship, whose purpose is to deter smear campaigning, have been upheld, Canon v. Justice Court, 61 Cal. 2d at 459, 393 P. 2d at 435,39 Cal. Rptr. at 235 (1964), but statutes actually prohibiting attacks on the basis of race or sex, for example, or prohibiting misrepresentations have been struck down as too heavy a burden on the freedom of speech, Vanasco v. Schwartz, 401 F. Supp. 87, 94 (E.D.N.Y.) (three-judge panel), aff'd, 423 U.S. 1041 (1975); see supra note 96; cf. Anderson v. Martin, 375 U.S. 399, 402 (1964) (the state may not print candidate's race on ballot because "by directing the citizen's attention to the single consideration of race or color, the State indicates that a candidate's race or color is an important-perhaps paramount-consideration in the citizen's choice, which may decisively influence the citizen to cast his ballot along racial lines."). 
thors of campaign literature may be disinclined to indulge in smear campaigns if forced to take credit for their writings. Although the court in Canon did not specifically mention the factor of "rational electoral outcomes," the court did stress the importance of elections being "the expression of the true public will."102 Canon suggests that in balancing first amendment interests courts may find that the societal interest in rational electoral outcomes is sufficiently important to justify some election laws even if such laws might have a somewhat chilling effect on speech. ${ }^{103}$

\section{Ensuring the Truth of Available Information}

An otherwise rational voter may reach a wrong decision if he or she acts on the basis of false information. ${ }^{104}$ Many states have enacted statutes that prohibit knowingly making false statements about political candidates. ${ }^{105}$ These statutes have been upheld against first amendment attacks made on the ground that they restrict freedom of political speech about candidates for public office. ${ }^{106}$ Frequently, courts that have upheld statutes prohibiting

${ }^{102}$ Canon, 61 Cal. 2d at 453, 393 P.2d at 430, 39 Cal. Rptr. at 430.

${ }^{103}$ The statutes discussed here ban only anonymous political campaign literature, and are thus distinguishable from the statute struck down in Talley v. California, 362 U.S. 60 (1960), which banned the distribution of any anonymous literature. Such a statute, the Court held, exerted an impermissible chilling effect on unpopular speech due to a fear of reprisal against the author. Id. at 64 . A more limited statute confined to political campaign literature has a smaller chilling effect, and is justified by the importance of the governmental interests asserted. United States v. Scott, 195 F. Supp. 440, 444 (1961); Canon v. Justice Court, 61 Cal. 2d 446, 460, 393 P.2d 428, 436, 39 Cal. Rptr. 228, 236 (1964); see also First Nat'l Bank v. Bellotti, 435 U.S. 765, 792 n.32 (1978).

104 See supra text accompanying notes 30 and 38.

${ }^{108}$ See, e.g., Alaska Stat. \$ 15.56.010 (a)(3) (1982); Colo. Rev. Stat. \$ 1-13-109 (1980); Mass. Gen. Laws ANn. ch. 56, $\$ 42$ (West 1973); MnN. Stat. Ann. $\S 210 A .04$ (West 1962); Miss. Code Ann. § 23-3-33 (1972); Mont. Code Ann. § 13-35-234 (1981); N.C. Gen. Stat. § 163-274(8) (1982); N.D. Cent. Code § 16.1-10-04 (1980); Ohio Rev. Code ANN. § 3599.091(B) (Page Supp. 1982); OR. Rzv. Stat. § 260.532 (1981); Tenn. Code ANn. § 2-19-142 (1979); Utah Code Ann. \$ 20-14-28 (1976); Wash. Rev. Code Ann. \$29.85.070 (1965); W. VA. Code § 3-8-11(e) (1979); WIs. STAT. ANN. § 12.17 (West 1967). Some such statutes prohibit only false statements reflecting on the honesty, integrity, or moral character of the candidate, see, e.g., Alaska Stat. § 15.56.010(a)(3) (1982); Miss. Code AnN. § 23-3-33 (1972); Mont. CoDE ANN. \& 13-35-234 (1981); others prohibit falsehoods of any kind "relating to" a candidate, see, e.g., Or. Rev. Stat. § 260.532 (1981); see also Colo. Rev. Stat. § 1-13-109 (1980); Mass. Gen. Laws Ann. ch. 56, $\$ 42$ (West 1973); Tenn. Code Ann. § 2-19-142 (1979); Utar Codz Ann. § 20-14-28 (1976); Wash. Rev. Code Ann. $§ 29.85 .070$ (1965); Wis. Stat. AnN. § 12.17 (West 1967).

${ }^{100}$ One line of cases involves a candidate misrepresenting his opponent's voting or prosecutorial record. See Schiebel v. Panlak, 282 N.W.2d 843 (Minn. 1979); DeWine v. Ohio Elections Comm'n, 61 Ohio App. 2d 25, 399 N.E.2d 99 (1978); Sumner v. Bennett, 45 Or. App. 275, 608 P.2d 566 (1980). Another line of cases involves misrepresentations made by a candidate about himself. See Schmitt v. McLaughlin, 275 N.W.2d 587 (Minn. 1979); 
false campaign statements against first amendment challenges have reasoned that the statutes were constitutional because they required actual malice on the part of the maker of the false statement and thus did not seriously threaten to chill speech. ${ }^{107}$ While these courts have primarily emphasized the unfairness of false statements to the maligned candidates, their reasoning has also acknowledged the harm to the public and the democratic system when individuals are elected to office on the basis of misinformation:

Nothing is more important in a democracy than the accurate recording of the untrammeled will of the electorate. Gravest danger to the state is present where this will does not find proper expression due to the fact that electors are . . . misled ... . It is . . . possible and feasible to require of candidates that statements known to be false and so substantially bearing upon the fitness of other candidates as to have a tendency to influence votes, shall not be made the basis of appeals for votes .....108

Statutes that prohibit the knowing making of false statements about political candidates foster rational electoral outcomes by improving the accuracy of the information on which voters base their electoral decisions. The courts implicitly acknowledge that voters may be persuaded by false information and therefore may vote in a way that subverts rather than enhances good government. Accordingly, where calculated falsehoods threaten electoral rationality, the first amendment balance may be struck so as to permit the restraint of the offending speech.

Menkerly v. Lefebrue, 1303 N.W.2d 462 (Miss. 1981); Rook v. Skrus, 262 N.Y.S.2d 968 (1965); Benan v. Garrett, 586 P.2d 1119 (Or. 1978).

107 See, e.g., DeWine v. Ohio Election Comm'n, 61 Ohio App. 2d 25, 33, 399 N.E.2d 99, 102-03 (1978). The source of the "actual malice" test used by the courts in such cases is New York Times Co. v. Sullivan, 376 U.S. 254 (1964), where the Court held that a libel plaintiff who is a public figure is required to prove malice in order to recover, since otherwise potential libel recoveries would chill speech about public officials. Id. at 279 .

108 State ex rel. Hampel v. Mitten, 227 Wis. 598, 603, 278 N.W. 431, 435 (1938) (dictum). The Hampel court also said that the "tendency of such false statements to affect the result of an election . . . is obvious upon its face." Id. at 608, 278 N.W. at 438. The Supreme Court has stated that "the use of the known lie as a tool is at once at odds with the premises of a democratic government and with the orderly manner in which economic, social or political change is to be effected." Garrison v. Louisiana, 379 U.S. 64, 75 (1964) (holding that the constitution limits state power to impose sanctions for criticism of the official conduct of public officials to false statements concerning official conduct made with knowledge of their falsity or with reckless disregard as to whether they were false or not). 


\section{Decisions Failing to Promote the Rationality of Electoral Outcomes}

\section{A. Rudisill v. Flynn}

Courts do not always act to promote rational electoral outcomes, as the case of Rudisill v. Flynn ${ }^{109}$ demonstrates. In that case, the voters of an Illinois town voted on a public bond issue to finance a construction project. ${ }^{110}$ Certain members of the town council who stood to gain financially from the construction project waged a campaign for approval of the referendum in which they deliberately understated the cost of, and overstated the need for, the project. ${ }^{111}$ The voters approved the project, and plaintiffs, voters in the election, sued to set aside the results of the referendum on the equal protection and due process grounds that the defendants' fraud impaired their fundamental right to vote. ${ }^{112}$ The Court of Appeals for the Seventh Circuit affirmed the dismissal of the cause of action for three reasons. First, since the voters did not misunderstand the issue as it was placed on the ballot and were free to vote for or against it, the court reasoned that the defendants' wrongs were not sufficiently connected with the right to vote itself. ${ }^{113}$ Second, the court reasoned that even if the plaintiffs' right to vote was affected, the burden placed on it by the defendants' fraud would be outweighed by the infringement on the defendants' rights of freedom of expression that would result from voiding the referendum. ${ }^{114}$ Third, the plaintiffs failed to allege or show as an element of their equal protection claim that, one group was more affected in its right to vote by the defendants' conduct than was another. ${ }^{115}$

The court's first reason has the most bearing on this comment's consideration of how a governmental interest in rational electoral outcomes might have affected this case. The plaintiffs argued that the "defendants' 'frauds' prevented the voters from making an intelligent choice,"116 but the court seemed reluctant to enter into the intricacies of ballot issues and the standard for their presentation to the voters: "The merits of a ballot issue are mat-

\footnotetext{
109619 F.2d 692 (7th Cir. 1980).

$110 \mathrm{Id}$. at 693.

111 Id.

113 Id. at 694.

113 Id.

314 Id. at 695.

118 Id.

116 Id. at 694.
} 
ters reserved for public and private discussion and debate between opponents and proponents. It is for the voters, not this court to decide whom to elect and what ballot issues to approve."117

From the standpoint of assuring electoral rationality, the court's analysis is inadequate. The court apparently assumed either that voters can detect falsehoods when confronted with them, an ability that voting theory does not ascribe even to rational voters, ${ }^{118}$ or that the marketplace of ideas can generally be relied upon to produce a rebuttal to false information, certainly an unlikely proposition in this case. ${ }^{110}$ Voters may require even greater protection from false speech concerning ballot issues than they do from false speech about candidates. Referenda, unlike elections, involve the direct participation of citizens in the lawmaking process. Knowledge of the meaning of a referendum vote is often made difficult by the confusing and technical language of ballot measures. ${ }^{120}$ Unlike elections, where voters may be able to select somewhat rationally on the basis of intangible factors such as the candidates' character, referenda admit of no substitute for a thorough understanding of the issues. ${ }^{121}$ Though the result in Rudisill might be explained by the absence of a statute banning false statements about referenda, ${ }^{122}$ by the fact that the plaintiffs brought their claims under the equal protection and due process clauses, or by the extreme remedy of invalidation requested, ${ }^{123}$ the opinion displays a troubling insensitivity to considerations of electoral rationality.

112 Id.

118 See supra note 30 and accompanying text.

119 The information at issue in Rudisill-the cost and need for the project-was technical and peculiarly within the control of the town council, the very perpetrators of the fraud. It is unreasonable to expect that laymen could find the information necessary to rebut the contentions of town council members. See Rudisill v. Flynn, 479 F. Supp. 1269, 1271 (N.D. IIl. 1979), aff'd, 619 F.2d 692 (7th Cir. 1980).

120 See Brown v. Superior Court, 5 Cal. 3d 509, 522, 487 P.2d 1224, 1233, 96 Cal. Rptr. 584, 593 (1971); Note, The California Initiative Process: A Suggestion for Reform, 48 S. Cal. L. Rev. 922, 934-937 (1975) (ballot measures typically complex and difficult to understand).

${ }^{121}$ See Note, supra note 120 , at 939.

122 At least five states have prohibited false statements about ballot issues by statute. Colo. Rev. Stat. $\S 1-13-109$ (1973) ("any issue"); Mass. Ann. Laws ch. 56, $\$ 42$ (Michie/ Law. Co-op. 1973) ("any question submitted to the voters"); N.D. CENT. CODE \& 16.1-10-04 (1980) (initiatives, referenda, constitutional amendments); OR. REv. STAT. § 260.532 (1981) ("any. . . measure"); UTAF CODE ANN. § 20-14-28 (1976) ("proposed constitutional amendment or other measure").

${ }^{123}$ Rudisill, $619 \mathrm{~F} .2 \mathrm{~d}$ at 693. 


\section{B. Buckley v. Valeo and its Progeny}

In Buckley $v$. Valeo, ${ }^{124}$ the Supreme Court ruled on the constitutionality of the major provisions of the Federal Election Campaign Act ("FECA," or "the Act"). ${ }^{125}$ The Act set ceilings on contributions by individuals to political candidates, ${ }^{128}$ independent expenditures by individuals on behalf of candidates, ${ }^{127}$ and campaign spending by candidates for federal office. ${ }^{128}$ The Act also mandated disclosure of contributions and expenditures above a

124424 U.S. 1 (1976). Buckley has prompted a substantial body of commentary. See, e.g., Clagett \& Bolton, Buckley v. Valeo, Its Aftermath, and Its Prospects: The Constitutionality of Government Restraints on Political Campaign Financing, 29 VAND. L. Rev. 1327 (1976) (predicting likely problem areas in election law after Buckley); Polsby, Buckley v. Valeo: The Special Nature of Political Speech, 1976 Sur. Cr. Rev. 1 (in Buckley, Court rejected Meiklejohn's view that free speech should be evaluated in terms of democratic selfgovernment). Much of the commentary has been critical. See Cox, Foreward: Freedom of Expression in the Burger Court, 94 HARv. L. REv. 1, 55-70 (1980) (packaging of political candidates will be more important after Buckley and subsequent decisions); Nicholson, Buckley v. Valeo: The Constitutionality of the Federal Election Campaign Act Amendments of 1974, 1977 WIs. L. Rev. 323 (Court second-guessed Congress as to need for expenditure limitations to prevent corruption); Wright, Money and the Pollution of Politics: Is the First Amendment an Obstacle to Political Equality?, 82 CoLUM. L. REv. 609 (1982) (Court's ritual absolute protection of speech allows distortion of electoral process by money); The Supreme Court, 1975 Term, 90 Harv. L. Rsv. 56, 171 (1976) (Court in Buckley focused too narrowly on quid pro quo corruption); Comment, Buckley v. Valeo: The Supreme Court and Federal Campaign Reform, 76 CoLum. L. Rev. 852 (1976) (Court failed adequately to address equalization of political access rationale).

${ }_{12 s}$ Pub. L. No. 92-225, 86 Stat. 3 (1971), as amended by Pub. L. No. 93-443, 88 Stat. 1263 (1974) (codified as amended at 2 U.S.C. $\$ \S 431-456$ (1982) and in scattered sections of $18 \& 47$ U.S.C.).

128 "Contribution" is defined at 2 U.S.C. $\$ 431$ (8) (1982):

(8)(A) The term "contribution" includes-

(i) any gift, subscription, loan, advance, or deposit of money or anything of value made by any person for the purpose of influencing any election for Federal office; or

(ii) the payment by any person of compensation for the personal services of another person which are rendered to a political committee without charge for any purpose.

The statute excludes from this definition such items as the value of volunteered services and contributed facilities. Id. $\$ 431(8)(\mathrm{B})$.

127 "Expenditure" is defined at 2 U.S.C. $\S 431(9)$ :

(9)(A) The term "expenditure" includes-

(i) any purchase, payment, distribution, loan, advance, deposit, or gift of money or anything of value, made by any person for the purpose of influencing any election for Federal office; and (ii) a written contract, promise, or agreement to make an expenditure.

Excluded are such items as independent news stories, communications by corporations to their stockholders, and certain mailings by committees of political parties. Id. § 431(9)(B). In essence, the difference between a contribution to a candidate and an expenditure for a candidate is that the contribution is given to the candidate to spend as he or she deems fit while the expenditure is made on behalf of the candidate in a manner chosen by the donor.

12 2 U.S.C. $\$ 441 \mathrm{a}(1982)$. 
certain level, ${ }^{129}$ created a system of public financing of presidential campaigns, ${ }^{130}$ and established the Federal Election Commission to oversee and enforce the legislation. ${ }^{131}$ The Court upheld much of the Act, including the contribution limitation, but struck down the independent expenditure limitations. ${ }^{132}$

Congress intended the expenditure limitations to prevent wealthy contributors from evading the limitations on contributions to candidates by spending independently on behalf of candidates. ${ }^{138}$ Together with the contribution and campaign spending limitations, these provisions created a scheme to reduce the role of money in federal elections. Congress created this scheme to deter corruption and the appearance of corruption among federal officials $^{134}$ by taking away the ability of individuals to make large contributions to, or expenditures on behalf of, a candidate. These limits were thought to reduce the likelihood that a successful candidate would actually or apparently be beholden to his benefactors. ${ }^{13 s}$ Congress also wished to equalize, to some extent, the chances for election of rich and poor candidates, or those with rich and poor supporters, by limiting the ability of affluent or wellfinanced candidates to win elections by outspending their poorer rivals. ${ }^{136}$

This latter purpose of equalizing campaign expenditures has two distinct roots. Fairness is one obvious consideration. The other important though frequently overlooked concern expressed by Congress is that voters are unduly influenced by, and therefore respond irrationally to, the sheer volume of information communicated by wealthy candidates. ${ }^{137}$ Concern for the irrational effects of

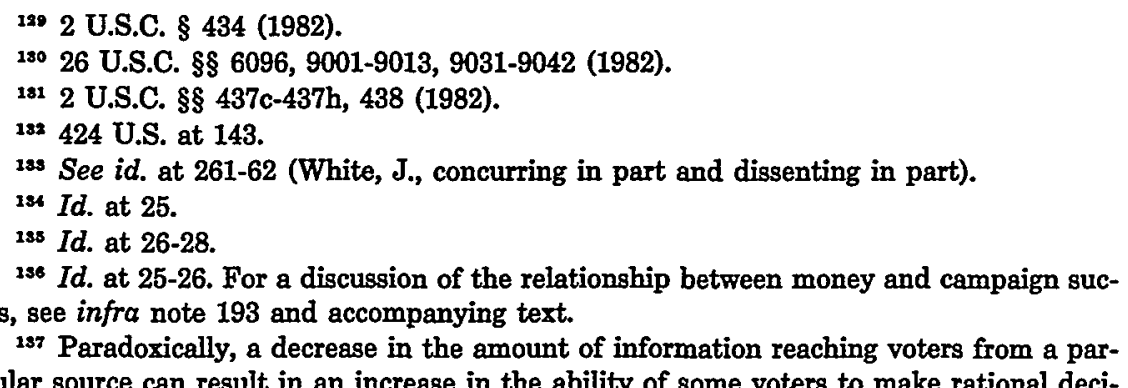
ticular source can result in an increase in the ability of some voters to make rational deciimparts little or no new information to the voter; such exposure may, however, cause the voter to respond unduly favorably to the candidate whose advertisements he or she sees most frequently. See T. PATterson, Thr Mass Mrdia Elrgction (1980) (effectiveness of television in influencing voters); cf. Red Lion Brosdcasting Co. v. FCC, 395 U.S. 367 (1969) (Court upheld FCC's "fairness doctrine" requiring balanced radio and television coverage of both sides of public issues). The campaign spending limits envisioned by Congress contem- 
differential levels of exposure appears throughout the legislative history of FECA. For example, an early version of the bill which became FECA limited candidates' expenditures on media advertising. ${ }^{138}$ The house report accompanying that bill stated:

This will make possible parity of exposure on these media as between candidates competing for the same Federal elective office. Thus, such candidates will be competing for votes of the electorate on their merits rather than on the basis of exposure as in the case of such commodities as toothpaste, soft drinks and beer, aspirin, and razor blades. ${ }^{130}$

Throughout the course of lengthy debates on FECA itself, the enactors worried repeatedly that voters have been "conditioned"140 to respond to "superficial advertising"141 rather than a candidate's "qualifications" or "record."142 While the Congressmen understandably did not label their constituents "irrational," they demonstrated concern for the rationality of electoral outcomes. ${ }^{143}$

Nonetheless, the Court in Buckley, reflecting the arguments briefed by the parties, ${ }^{144}$ never took into consideration Congress's

plated no reduction in the amount of information reaching voters, but only a reduction in the frequency with which certain information is presented. A voter can tell nothing useful about a candidate's qualifications for office from the fact that he airs twice as many television commercials as his opponent. The real danger of votes based on exposure is that they may reflect a total failure of judgment on the part of the voter, see supra note 28 , and rest instead only on a subconscious and irrational name association similar to that found to exist in the ballot placement and electioneering cases, see supra notes 44-76 and accompanying text.

${ }_{138}$ H.R. 8628, 92d Cong., 1st Sess. $\$ 5$ (1971).

130 H.R. REP. No. 565, 92d Cong., 1st Sess. 19 (1971).

140 According to Representative Ichord, "In an affluent society where people are conditioned to buy certain products by high-powered public relations and advertising specialists ... it is becoming easier to 'sell' a candidate with the money to buy the TV time." 117 CoNG. REc. 42,076 (1971). Representative Madden urged a limitation on expenditures "so that the minds of the American voters are not high-pressured and warped with multi-million-dollar financed political propaganda . ..." Id. at 42,056 .

14 Senator Muskie decried the fact that "millions are spent to sweep men into office on a wave of superficial advertising more appropriate to soap or cereal than national politics . . . ." Id. at 29,321.

142 So great is the power of money in politics, said Representative Conte, that "[t]he best of intentions, the highest qualifications, an admirable record-all of these can be overridden by massive, expensive campaign practices and gimmicks." Id. at 42,068; see also id. at 29,322 (remarks of Sen. Talmadge), 30,072 (remarks of Sen. Hart), 42,063 (remarks of Rep. Staggers), 42,072 (remarks of Rep. Thompson).

14s See infra notes 230-34 and accompanying text.

14 See Brief for the Attorney General and the United States at 52-57, Buckley v. Valeo, 424 U.S. 1 (1976); Brief for the Attorney General and the Federal Election Comm'n at 2327, Buckley v. Valeo, 424 U.S. 1 (1976); Brief for Appellees Center for Public Financing of Elections at 65-66, Buckley v. Valeo, 424 U.S. 1 (1976). 
purpose of limiting a candidate's ability to buy superficial "conditioning." FECA's provisions were challenged on constitutional, principally first amendment, grounds. The individual contribution limits were challenged on the ground that they violated the freedom of association protected by the first amendment. ${ }^{145}$ Adopting a test of "the closest scrutiny," which required the government to show a sufficiently important interest and a narrowly drawn abridgement of the freedom, ${ }^{146}$ the Court held that the contribution limitation was justified by the important government interest in preventing the corruption and the appearance of corruption that unlimited personal contributions can entail. ${ }^{147}$

The first amendment challenges to the expenditure limitations, however, met with greater success. The Court first rejected a vagueness challenge by narrowly contruing those provisions as applying only to expenditures on communications that expressly advocated the election or defeat of a clearly identified candidate for federal office. ${ }^{148}$ By then applying the same "closest scrutiny" test because the same associational rights were at stake, ${ }^{148}$ the Court held that no governmental interest was asserted that was sufficient to justify the burden on the right to free speech and association. ${ }^{160}$ The Court found that, even under its narrow construction, the expenditure limitations could not prevent corruption, because supporters could still make expenditures so long as they were not explicit in their electoral message. ${ }^{151}$ Also, the court reasoned, the indirect nature of the campaign expenditure alleviated the risk of a quid pro quo from the candidate and thereby vitiated the strength of the principal argument in favor of the limitation-that the prevention of corruption and the appearance of corruption justified the burden of a limitation on the first amendment right to " speak one's mind." "152 Finally, the Court reasoned, "equalizing" expendi-

14 Buckley, 424 U.S. at 25.

146 Id. at 25-29.

147 Id. The Court also rejected arguments that the individual contribution limitations were overbroad, id. at $29-30$, and invidiously discriminatory to minor party and independent candidates, id. at 35-36. The Court upheld the constitutionality of the $\$ 5000$ limitation on contributions by political committees, id. at $36-37$, and the $\$ 25,000$ limitation on an individual's total annual contributions to all candidates, id. at 38 , on the same ground: that the governmental interest in deterring corruption and the appearance of corruption justified these additional restrictions on the freedom of association.

148 Id. at $39-44$.

169 Id. at 44.

$130 \mathrm{Id}$. at 45.

$161 \mathrm{Id}$. at $45-46$.

182 Id. at 48. The Court's distinction between limits on contributions and expenditures was criticized by Chief Justice Burger, id. at 241-46, who would have struck down both 
tures in order to equalize candidates' access to the electorate is "wholly foreign" to the first amendment, the purpose of which is to secure the widest possible dissemination of information from all sources. ${ }^{163}$

Had the parties or the Court focused on considerations of electoral rationality, the Court might have balanced the interest in rational electoral outcomes against the first amendment restraints posed by the statute. Instead, the Court looked only to the interest of the government in affording citizens a fair opportunity, through an equalization of expenditures, to express themselves, ${ }^{154}$ and

types of limits, and by Justice White, id. at 260-62, who would have upheld both limits. Commentators have also criticized this distinction on the ground that it allows unscrupulous individuals to evade the contribution limitations by spending large amounts on behalf of candidates. Forrester, The New Constitutional Right to Buy Elections, 69 A.B.A. J. 1078, 1080 (1983); Note, Making Campaign Finance Law Enforceable: Closing the Independent Expenditure Loophole, 15 U. MrcH. J.L. RER. 363 (1982) (discussing problem of coordination between candidates and independent spenders). It has been suggested that subsequent opinons of the Court may be read to reject Buckley's distinction between expenditures and contributions, and that a majority of the Court now view limits on either as unconstitutional. Richards, The Rise and Fall of the Contribution/Expenditure Distinction: Redefining the Acceptable Range of Campaign Finance Reforms, 18 NEw Eng. L. REv. 367, 393 (1982-1983).

18s 424 U.S. at 48-49. The Court also held that restrictions on a candidate's freedom to spend his own money on his own campaign was an impermissible burden on the candidate's right to advocate his own election "vigorously and tirelessly." Id at 52. The Court reasoned that there could be no risk of corruption from a candidate's spending his own money; therefore there was no sufficient governmental interest justifying the restriction. Id. at 53. The Court considered the argument that such limits would help equalize total campaign expenditures, but gave the argument little weight, reasoning that the effect of the limits would be insignificant compared to that resulting from differential success rates at fundraising. Id. at 54. Finally, the Court struck down limitations on total campaign expenditures, arguing that corruption could be better prevented through contribution limitations, and that equalization of expenditures might well handicap lesser-known candidates. Id. at 54-59.

${ }_{184}$ Cast only in terms of fairness, the controversy in Buckley revolved not around the constitutionality of legislation seeking to promote rational electoral outcomes, but around considerations of wealth, a factor which has found little place in the Burger Court's constitutional jurisprudence. See, e.g., San Antonio Indep. School Dist. v. Rodriguez, 411 U.S. 1 (1973) (in equal protection context, wealth not a suspect category); Wright, supra note 124 (money, although critical in elections, is not treated by the Court as such). It is unsurprising that the Court, tacitly employing a balancing test, should prefer free speech over governmental correction of the inequitable distribution of wealth. On the other hand, wealth and electoral rationality are intimately related in the context of media campaigning. See supra notes 137-43 and accompanying text. Language elsewhere in the Buckley opinion suggests that the Court might have been more receptive to an argument based on a government interest in promoting rational electoral outcomes. E.g., 424 U.S. at 14-15 ("In a republic where the people are sovereign, the ability of the citizenry to make informed choices among candidates for office is essential"), 49 n.55 ("Democracy depends on a well-informed electorate"), 52-53 (candidates must be able to put views before public "so that the electorate may intelligently evaluate the candidates' personal qualities and their positions"); see infra text accompanying note 163 . 
found it negligible: "[T]he concept that government may restrict the speech of some elements of our society in order to enhance the relative voice of others is wholly foreign to the First Amendment "165 The reach of this language is not entirely clear. The Court might have viewed the government's interest in guaranteeing electoral rationality as the kind of government regulation of speech that, however potentially beneficial, was rejected by the framers in favor of a free market of ideas. More likely, though, the Court failed to consider electoral rationality when it struck down the expenditure limitations.

In First National Bank v. Bellotti, ${ }^{156}$ the Court confirmed the hostility to limitations on campaign expenditures first evidenced in Buckley. The election law at issue in Bellotti was a Massachusetts statute prohibiting corporations from spending money to influence votes on ballot measures. ${ }^{157}$ The state attempted to justify this measure on the ground that it reduced the influence of wealthy corporations on electoral outcomes. ${ }^{158}$

${ }^{165} 424$ U.S. at $48-49$. The Court expressly tied spending money to speech, calling - money the "gasoline" in the "automobile" of expression, id. at $19 \mathrm{n.18}$, and considered expenditure of money to be a form of association, $i d$. at 22. In the words of Justice White, the Court decided that "money talks." Id. at 262 (White, J., concurring in part and dissenting in part). The Court therefore had to assess the statute's limitations on expenditures of money under the first amendment. Id. at 14-23. Justice White disagreed with this portion of the Court's reasoning, arguing that the effect on speech of restricting expenditures is incidental. Id. at 262-64. According to Justice White, the Court's reasoning could justify the prohibition of any activity, such as taxation, that "siphon[s] off or prevent[s] the accumulation of large sums that would otherwise be available for communicative activities." Id. at 263. Judge Skelly Wright has argued that spending money is a "form of conduct related to speech," but is not speech itself. Wright, Politics and the Constitution: Is Money Speech?, 85 Yale L.J. 1001,1006 (1976). In his view, FECA's expenditure limitations targeted money itself, divorced from the kind of communication it could buy, $i d$. at 1008, and thus should have been subjected to a less demanding standard than that applied by the Court.

${ }^{188} 435$ U.S. 765 (1978). For commentary on Belloti, see Fox, Corporate Political Speech: The Effect of First National Bank of Boston v. Bellotti Upon Statutory Limitations on Corporate Referendum Spending, $67 \mathrm{Ky}$. L.J. 75 (1978-79) (Bellotti violated first amendment principles of listeners' rights, laissez-faire marketplace of ideas, protection of commercial speech); Hart \& Shore, Corporate Spending on State and Local Referendums: First National Bank of Boston v. Bellotti, 29 CASE W. RES. L. Rev. 808 (1979) (reaffirms basic first amendment rights); Miller, On Politics, Democracy, and the First Amendment: $A$ Commentary on First National Bank v. Bellotti, 38 WASH. \& LEE L. REv. 21 (1981) (Bellotti is part of anti-democratic, Burkeian counter-revolution against perceived excesses of democracy); The Supreme Court, 1977 Term, 92 HARv. L. REv. 57, 171 (1978) (taken together, Buckley and Bellotti properly eliminate state's interest in preventing undue corporate influence in politics); Note, First National Bank of Boston v. Bellotti: The Reopening of the Corporate Mouth-The Corporation's Right to Free Speech, 21 ARIz. L. REv. 841 (1979) (approving of Court's analysis).

167435 U.S. at 767-68.

${ }^{188} I d$. 
The Supreme Court struck down the Massachusetts law as a violation of the first amendment. The Court emphasized that "the First Amendment goes beyond protection of the press and the selfexpression of individuals to prohibit government from limiting the stock of information from which members of the public may draw."159 Using an "exacting scrutiny" test, the Court found that neither the state's interest in "sustaining the active role of the individual citizen in the electoral process" nor its interest in protecting the rights of minority shareholders who disagreed with the corporation's stance was sufficiently compelling to justify the subjectmatter restriction of the statute. ${ }^{160}$ The Court recognized the importance of individual participation in ballot measure campaigns, but reasoned that people in America were "entrusted with the responsibility for judging and evaluating the ... a arguments" put forth in a campaign by considering the source of those arguments. ${ }^{181}$ The Court also reasoned that the Massachusetts legislation was underinclusive if its purpose was the protedtion of minority stockholders because it permitted corporations to make other expenditures and engage in other forms of expression without protecting those minority rights. ${ }^{162}$ The Court did claim that, if presented with a proper record, it would consider legislative findings that corporations possess a power to drown out the views of others if that power "threatened imminently to undermine democratic processes." "16s The Court's general reasoning, however, that the first amendment precludes "paternalism" through state limitations on campaign speech, ${ }^{164}$ suggests that even such findings might not be persuasive.

Finally, in Citizens Against Rent Control v. City of Berkeley, ${ }^{168}$ the Supreme Court expanded its already broad reading of the first amendment in the area of campaign finance by, for the first time, striking down a statute limiting political contributions.

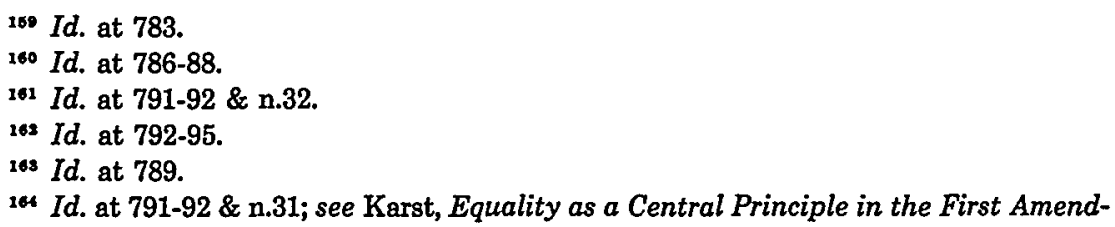
ment, 43 U. CHI. L. REv. 20, 63 (1975); see also infra notes 173-80 and accompanying text.

${ }^{165} 454$ U.S. 290 (1981). For commentary on City of Berkeley, see The Supreme Court, 1981 Term, 96 HARv. L. REv. 62, 161 (1982) (Court adopted laissez-faire view of marketplace of political ideas as long as voters know the source of information); Note, Citizens Against Rent Control v. City of Berkeley: Constitutionality of Limits on Contributions in Ballot Measure Campaigns, 69 CAL. L. REv. 1001 (1981) (although law was paternalistic, Court should have remanded for factual findings on distortion of referendum process by spending). 
In City of Berkeley, the California Supreme Court had upheld a city ordinance enacted to reduce the ability of special interest groups to corrupt the initiative process by spending large amounts of money, by limiting contributions by individuals to groups advocating or opposing ballot measures. ${ }^{166}$ The ordinance was challenged as unduly burdening the freedoms of association and expression. ${ }^{16 z}$ The United States Supreme Court reversed, holding that Buckley's approval of contribution limitations does not apply to ballot measures, since there is no possibility of corruption resulting from spending on behalf of ballot measures. ${ }^{168}$

Taken together, these cases reveal a serious inconsistency in the judicial approach to problems of voting behavior. In ballot placement, electioneering, disclosure, and truth of campaign information cases, courts have taken a broad view of what measures are permissible to enhance rational voting. This commitment to rational electoral outcomes, however, does not carry over to cases that regulate the volume of information reaching voters by limiting campaign expenditures and contributions. In these cases, the Supreme Court has struck down legislation, arguably promoting electoral rationality, despite congressional and state legislative findings of voter irrationality.

These holdings leave the law in an anomalous state. The same voters who vote for a candidate because his name appears first on the ballot, or because, immediately before entering the voting booth, their eyes light on a sign or button displaying his name, or because they cannot resist the influence of innuendo and smear attacks launched by the candidate against his opponent-these same voters are abandoned to the influences of lengthy, high-pressure media blitzes, ${ }^{169}$ influences that Congress, state legislatures, and even the Supreme Court have conceded affects them. ${ }^{170}$

\section{The First Amendment And Rational Voting}

A. The First Amendment Commitment to a Model of Rational Voting Behavior

While legislatures have decried, and some lower courts have

160454 U.S. at $292-93$.

107 Id. at $293-94$.

${ }^{168}$ Id. at $296-99$.

169 See R. Spero, The Duping of THE American Voter passim (1980) (review of tactics used by presidential candidates in television advertising); see also infra notes 186-99 and accompanying text.

370424 U.S. at 26-27. 
acknowledged, the threat that unlimited speech poses to the pursuit of rational electoral outcomes, the Supreme Court has failed to address the problem in the context of political expenditures. Traditional first amendment doctrine has shaped the Court's response to volume of information cases: disclosure requirements are permitted, on the ground that their chilling effect on speech is slight in comparison to the additional information they provide, ${ }^{171}$ while laws limiting the volume or amount of information are not permitted, since they directly restrict freedom of speech. ${ }^{172}$ The Court's decisions striking down limits on campaign contributions and expenditures suggest that the Court may interpret the first amendment as embodying a belief that voters can be counted on to act rationally and that therefore the government has no compelling interest in restricting those forms of speech that might encourage irrational voting behavior. Thus, in First National Bank v. Bellotti, ${ }^{173}$ the Court described the task of voters:

[T] he people in our democracy are entrusted with the responsibility for judging and evaluating the relative merits of conflicting arguments. They may consider, in making their judgment, the source and credibility of the advocate. But if there be any danger that the people cannot evaluate the information and arguments advanced by [a speaker], it is a danger contemplated by the Framers of the First Amendment. ${ }^{174}$

In a more recent case, the Court stated that the first amendment "embodies our trust in the free exchange of ideas as the means by which the people are to choose between . . . candidates for public office. The State's fear that voters might make an illadvised choice does not provide the State with a compelling justification for limiting speech."17s In the Court's view, then, even a legislative finding of danger to the democratic process from widespread irrational voting cannot overcome the first amendment presumption of voter rationality. ${ }^{178}$ But when voters in large numbers behave irrationally, as we now have good reason to believe they do,

${ }^{171}$ See supra notes 90,105 and accompanying text.

172 See Buckley, 424 U.S. at 18.

173435 U.S. 765 (1978).

174 Id. at 791-792 (footnotes omitted); see also Easley, Buying Back the First Amendment: Regulation of Disproportionate Corporate Spending in Ballot Issue Campaigns, 17 GA. L. Rzv. 675, 725 (1983) ("Whatever risk exists that people will . . . be wrongly persuaded is a risk the first amendment demands we take . . . .").

${ }^{175}$ Brown v. Hartlage, 456 U.S. 45, 60 (1982) (state cannot bar candidate from pledging, if elected, to lower salaries of public officials).

178 Id. 
this traditional gloss on the first amendment stands in the way of achieving rational electoral outcomes. ${ }^{177}$

The primary concern of the framers of the Constitution in guaranteeing freedom of speech in the first amendment was a fear of regulation of speech as a tool of government oppression. ${ }^{178}$ The dangers of government regulation of speech are gravest in the context of political campaigns: "The fear that a prevailing government might some day wield its power over political campaigns so as to perpetuate its rule generates a commendable reluctance to invest government with broad control over the conduct of political campaigns." ${ }^{179}$ In light of these dangers, the first amendment is understood to deny to government the power over speech, and instead to allocate that power to the people. ${ }^{180}$ Implicit in this allocation is one of two assumptions: either that the people can use their power wisely, or, if they cannot, that the dangers of abuse of the power over speech by government exceed the dangers of abuse of that power by individuals. ${ }^{181}$

Today, nearly two centuries after the writing of the Constitution, the first of these assumptions-that the people know how to use their power of speech wisely-has been powerfully challenged. Political scientists have demonstrated that voter irrationality exists, ${ }^{182}$ casting doubt on the ability of the people to govern themselves intelligently. ${ }^{183}$ Congress, state legislatures, and some lower courts perceive a threat to the rationality of the electoral process and have attempted to facilitate rational voting and reduce the effects of irrational voting through various election laws. But in vol-

177 See supra notes $25,40-43$ and accompanying text.

${ }^{178}$ Kalven, The New York Times Case: A Note on "The Central Meaning of the First Amendment," 1964 Sup. Cr. Rev. 191, 208-209 ("The central meaning of the Amendment is that seditious libel cannot be made the subject of government sanction"); see Abrams v. United States, 250 U.S. 616, 630 (1919) (Holmes, J., dissenting).

179 L. TRIBE, supra note 21, §13-26, at 798; see also Karst, supra note 169, at 63.

${ }_{180}$ "Madison . . . said [that] . . . the censorial power is in the people over the Government, and not in the Government over the people." "New York Times Co. v. Sullivan, 376 U.S. 254, 275 (1964) (quoting 4 ANNaIS OF CoNGRESS 934 (1794)).

${ }^{182}$ Letter from Thomas Jefferson to John Taylor (May 28, 1815), reprinted in 6 THE WrItings of Thomas JEFrERSON 604, 608 (Washington ed. 1854) ("the evils flowing from the duperies of the people, are less injurious than those from the egoism of their agents"); Blasi, The Checking Value in First Amendment Theory, 1977 AM. B. Found. ResEarch J. 521, 538 ("The central premise of the checking value is that the abuse of official power is an especially serious evil-more serious than the abuse of private power . . . .").

182 See supra notes 25, 40-43 and accompanying text.

18s Cf. Meiklejohn, supra note 21, at 263 ("The primary social fact which blocks and hinders the success of our experiment in self-government is that our citizens are not educated for self-government."). 
ume-of-information cases, the Supreme Court has found that legally imposed limits on the amount of political speech in which an individual may engage transgress the first amendment's allocation of the power over speech to individuals instead of to the government. ${ }^{184}$ This result can no longer be justified if based solely on a belief in the ability of the people to use this power wisely. Moreover, the second assumption-that the danger of abuse of the power over speech by government exceeds the dangers of such abuse by individuals-is equally questionable.

\section{B. Money and Politics: The Danger of Unlimited Political Speech by Individuals.}

A crucial factor in American elections is money. Candidates annually spend millions of dollars in election contests; ${ }^{185}$ thousands of political action committees ("PACs") raise money to spend on behalf of candidates. ${ }^{188}$ The role of money in elections is critical, for there is a direct relationship between campaign spending and electoral success. ${ }^{187}$

One of the principal outlays in election campaigns is media advertising, particularly television commercials. ${ }^{188}$ Television expo-

184 See supra notes 155,164 and accompanying text.

${ }^{185}$ Candidates for public office spent $\$ 1.2$ billion in 1980. H. Alexander, Financing Politics 8 (1st ed. 1976) (3d ed. 1984). On the high cost of campaigns, see D. AddMany \& G. Agree, Political Money, 19-27 (1975); H. Alexander, supra, at 13-35.

186 Wertheimer, The PAC Phenomenon in American Politics, 22 ARIz. L. Rzv. 603 (1980) (documenting prevalence and effect of PACs). See generally Symposium: Political Action Committees and Campaign Finance, 22 ArIz. L. REv. 351 (1980). Twenty-five percent of all contributions to Congressional candidates come from PACs. Congressional. Quarterly, Inc., Dollar Politics 41 (3d ed. 1982).

${ }^{187} \mathrm{H}$. AleXANDER, supra note 191, at 41, 44. Jacobson, The Effects of Campaign Spending in Congressional Elections, 72 AM. PoL. Scr. Rev. 469 (1978) (relation between spending and voter recognition); Palda, The Effect of Expenditure on Political Success, 18 J.L. \& EcoN. 745 (1975) (spending influences electoral outcomes); Welch, The Effectiveness of Expenditures in State Legislative Races, 4 AM. PoL. Q. 333, 353 (1976) (spending influences electoral outcomes, but the law of diminishing returns applies). The correlation between money and electoral success does not, of course, mean that the candidate who spends the most will necessarily win. There is evidence that the marginal vote-getting productivity of campaign expenditures is less for incumbents than challengers. Adamany, PAC's and the Democratic Financing of Politics, 22 ARIz. L. Rev. 569, 573 (1980); Jacobson, supra, at 48283; see also Buckley v. Valeo, 424 U.S. 1, 31 n.33 (1976). In the area of ballot issues, one study has concluded that one-sided spending is effective when directed against a proposition, but ineffective when directed in support of a proposition. Lowenstein, Campaign Spending and Ballot Propositions: Recent Experience, Public Choice Theory and the First Amendment, 29 UCLA L. RBv. 505 (1982) (study of twenty-five California ballot propositions).

188 Candidates spent $\$ 58.9$ million on television advertising in 1968. H. ArexANDER, supra note 185 , at 28. 
sure heavily influences voters, ${ }^{189}$ and is frequently used in ways that exploit voter irrationality. ${ }^{100}$ The need for money to gain media access, ${ }^{191}$ the prevalence of media political campaigns, ${ }^{192}$ and the susceptibility of certain voters to the volume of media exposure of candidates, ${ }^{183}$ has brought about a situation where, in the judgment of Congress, "money [is] the principal determining factor of who is elected to Federal office."194 In other words, wealthy individuals may be in a position to "buy" public office by purchasing the media exposure necessary to exploit voter irrationality. Moreover, incumbents have a demonstrably greater ability to attract financial support. ${ }^{198}$ This being so, allowing unlimited expenditures enables incumbent government officials to do as private citizens what the first amendment forbids them to do in their official capacity-manipulate the electoral system in order to perpetuate themselves in office. ${ }^{198}$

A system of allocating offices on the basis of ability to pay is irrational; there is no relationship between wealth and the ability to lead the nation or promote its welfare. ${ }^{197}$ Wealth in the political arena thus stands on the same footing as systematic ballot placement, electioneering, anonymous support, and false information. Unlimited speech through money threatens popular democracy and, in turn, the general availability of rights such as freedom of

${ }^{189}$ In general, television has the capacity to "focus public attention." T. PATTERson, The Mass Media Election 99 (1980). It helps set the public agenda, id. at 97, influences voters' perceptions of candidates' chances to win, id. at 119-30, and creates a candidate's public image, $i d$. at 133-52. Television more effectively promotes candidate name awareness than print media. Id. at 111; see B. RuBIN, Political Television 18-20 (1967) (televised Nixon-Kennedy debates may have decisively influenced outcome of 1960 presidential election).

${ }^{180}$ See R. SPERo, supra note 169 , passim (documenting falsehoods and misrepresentations in television advertising by presidential candidates).

${ }^{101}$ See Wright, supra note 124 , at 620-25.

${ }^{102}$ See Buckley v. Valeo, 424 U.S. 1, 19 (1976); S. REP. No. 751, 91st Cong., 2d Sess. 6 (1970).

${ }^{103}$ See supra notes 139-53 and accompanying text.

184 117 Cong. REc. 42,063 (1971) (statement of Rep. Staggers); see H.R. REP. No. 564, 92d Cong., 1st Sess. 4 (1971).

105 See H. AleXander, supra note 185, at 54-57; A. Adamany \& G. Agree, supra note 191, at 25; Mansfield, Florida: The Power of Incumbency, in CAMPAIGN MonEy 39 (H. Alexander ed. 1976). Incumbents have additional advantages over challengers, including staff allowances, free office space, and the franking privilege. H. ALEXANDER, supra note 185, at 54-57.

190 See generally Wright, supra note 124, passim. But see supra note 187.

197 See supra note 137; cf. Harper v. Virginia Bd. of Elections, 383 U.S. 663, 668 (1966) (striking down poll tax on ground that "[w]ealth, like race, creed, or color, is not germane to one's ability to participate intelligently in the electoral process"). 
speech which popular democracy ensures. ${ }^{198}$

\section{Proposal: Balancing Freedom of Speech and Electoral RATIONALITY}

\section{A. A Balancing Test}

In the cases discussed in Part II, courts gave some consideration to electoral rationality, though they generally failed to identify it as such. They merely balanced the interest in electoral rationality along with any other interests ${ }^{189}$ against speech-related interests. Though it is difficult to articulate a consistent doctrine from this case-by-case balancing, the first amendment clearly tolerates some restrictions on speech when electoral rationality, or some proxy for it, is at issue. ${ }^{200}$

This comment calls on courts to acknowledge explicitly the government interest in rational electoral outcomes, and to include an analysis of that interest in the first amendment balancing of interests. The balancing equation should entail the traditional first amendment considerations: the immediacy of the danger ${ }^{201}$ presented by irrational voting, the existence of a content-differential effect on speech, ${ }^{202}$ the precision with which any given statute

${ }^{198}$ The power of government to restrict speech may seem more objectionable than the power of individuals to speak, but both may have identical results. For example, the counterpart of a government passing a law prohibiting speech critical of incumbents would be an individual spending huge sums of money to produce and capture irrational, exposure-based votes unavailable to a poorer rival. In both cases, the desired result-election of a particular candidate-is achieved through manipulation of the electoral system. In both cases, the likelihood of election of the most qualified candidate is reduced.

109 For example, in the electioneering cases, the government's interest in reducing electoral irrationality was accompanied by an interest in the administration of the voting process. In some cases, however, electoral rationality was the only interest counter-posed against free-speech concerns. For example, in the campaign literature authorship disclosure cases, all the asserted government interests related to the rationality of electoral outcomes. See supra text accompanying notes 91-103.

200 Where the restraint on speech is small, the showing required of the government has generally been held not to be great: "Unless the inhibition ... is significant, government need show no more than a rational justification for its choice." $L$. TRIBE, supra note $21, \S$ $12-20$, at 684 .

201 See Landmark Communications, Inc. v. Virginia, 435 U.S. 829 (1978) (disclosure of confidential information); Feiner v. New York, 340 U.S. 315 (1951) (provocation of hostile audience response); Bridges v. California, 314 U.S. 252 (1941) (in context of judicial process); Schenck v. United States, 249 U.S. 47 (1919) (establishing clear and present danger test in context of advocacy of illegal conduct).

${ }^{202}$ See Metromedia, Inc. v. San Diego, 453 U.S. 490 (1981) (billboards are not used to advance disproportionately any particular viewpoint); Police Dept. v. Mosley, 408 U.S. 92 (1972) (statute allowing all picketing except labor picketing is unconstitutional); Kovacs v. Cooper, 336 U.S. 77, 98 (1949) (Black, J., dissenting) (restricting use of sound trucks reduces 
restricts the offending speech, ${ }^{203}$ the availability of less restrictive alternatives, ${ }^{204}$ and the interest of society in the marginal loss of speech and information resulting from the restriction. ${ }^{205}$

This proposed balancing ${ }^{206}$ between freedom of speech and electoral rationality would have the following advantage over present pratcice. First, since such an approach has been implicitly adopted by state and federal courts in several areas where election

communicative ability of those who cannot gain access to other forms of mass communication).

${ }^{303}$ See Central Hudson Gas v. Public Serv. Comm'n of New York, 447 U.S. 557 (1980) (statutes regulating commercial speech must directly advance government interests); Gooding v. Wilson, 405 U.S. 518 (1972) (statute prohibiting abusive language overbroad where not limited to prohibition of fighting words); United States v. O'Brien, 391 U.S. 367 (1968) (in context of regulating symbolic conduct, statutes must restrict first amendment rights no more than necessary to accomplish government interests).

sot See Landmark Communications, Inc. v. Virginia, 435 U.S. 829 (1978) (protecting confidential information can be achieved by less restrictive means than prohibiting disclosure); Police Dept. v. Mosley, 408 U.S. 92 (1972) (prohibiting violence can be achieved by less restrictive means than banning labor picketing); Schneider v. State, 308 U.S. 147 (1939) (maintaining clean streets can be achieved by less restricive means than banning leafletting).

${ }^{205}$ See Landmark Communications, Inc. v. Virginia, 435 U.S. 829 (1978) (balancing danger of disclosure of confidential information against need for free expression); Buckley v. Valeo, 424 U.S. 1 (1976) (balancing danger of corruption against right to contribute to candidates); Branzburg v. Hayes, 408 U.S. 665 (1972) (balancing burden on reporters from disclosing sources against public need for information); Schneider v. State, 308 U.S. 147 (1939) (balancing government interests against freedom of speech).

${ }^{208}$ A related idea was raised by the government in United States v. C.I.O., 335 U.S. 106 (1948). That case concerned the validity of a section of the Federal Corrupt Practices Act, 61 Stat. 136, 159 (1947) (repealed 1948), which prohibited any corporation or labor union from making contributions to, or expenditures in connection with, candidates for political office. The government prosecuted the defendant labor union for distributing a publication endorsing a candidate in a congressional election, 335 U.S. at 108, and the union attacked the constitutionality of the statute under the first amendment, id. at 108-09. Justice Rutledge spelled out the government's defense of the statute as follows:

Congress has power to act to preserve the freedom and purity of federal elections under Art. 1, $\S 4$, of the Constitution . . . Thus it is claimed the First Amendment's guarantees are balanced by this other constitutional provision . . . . Accordingly, the usual preeminence accorded to the First Amendment liberties disappears, it is said, and the legislative judgment, having rational basis in fact and policy, becomes controlling.

Id. at 141 (Rutledge, J., concurring in the result). None of the Justices reached the merits of this argument. A majority of the Court avoided the constitutional issue by construing the statute as not applying to the union's conduct. Id. at 116 (plurality opinion), 129 (Frankfurter, J., concurring). Four Justices would have invalidated the statute on grounds of overbreadth, $i d$. at 141-42, 150 (Rutledge, J., concurring in the result), and vagueness, id. at 153 (Rutledge, J., concurring in the result).

The essence of the government's argument was that rationally based congressional actions authorized by the time, place, and manner clause of the Constitution take precedence over first amendment interests. The balancing test offered here differs from this argument in that it contends that the interest in rationality of elections is protected by inherent limitations in the scope of the first amendment itself. 
laws come into apparent conflict with the first amendment, ${ }^{207}$ its uniform adoption would incorporate this body of precedent, promoting consistency in application and result. Second, the balancing test would protect society's vital interest in rational electoral outcomes; electoral rationality might alone be a sufficient government interest, in certain situations, to justify restraints on the important interest of freedom of speech. Moreover, the test would allow courts to recognize the realities of irrational voting behavior and to develop first amendment doctrine to deal with the problems posed by electoral irrationality. Finally, the test would be no less protective of freedom of speech than that used by courts in other areas; it would incorporate safeguards from other contexts to allow a gradual and orderly development of first amendment doctrine. ${ }^{208}$

\section{B. Application of the Balancing Test}

Had the Buckley Court adopted the balancing approach suggested here, it might have reached a different result on the issue of expenditure limitations. The danger of irrational electoral outcomes caused by allowing unlimited contributions and expenditures is great. ${ }^{209}$ Congress considered the response of voters to candidate media exposure and deemed the problem serious. ${ }^{210}$ The statute was coherent and content-neutral. ${ }^{211}$ The statute attempted to curtail speech which imparted, at least in theory, no useful information. ${ }^{22}$ Even if the Court had found FECA too great a restraint on speech after considering these factors, Congress would have been free to document more clearly its concerns or to

\footnotetext{
${ }^{207}$ E.g., campaign disclosure and false campaign information cases. See supra text accompanying notes 93-108.

${ }_{208}$ The factors listed supra at text accompanying notes 201-05 were developed by the Court to provide a high degree of protection for speech in situations where the government seeks to abridge speech to serve some other governmental interest. For example, the doctrine of overbreadth requires legislatures to regulate speech with precision so that in restricting speech unprotected by the first amendment the state will not inadvertently punish protected speech as well. Thus, the Court has said, "[A] statute must be carefully drawn or be authoritatively construed to punish only unprotected speech and not be susceptible of application to protected expression." Gooding v. Wilson, 405 U.S. 518, 522 (1972).

200 See supra text accompanying notes 17-23, 40-43, 195-98.

210 See supra notes 138-43 and accompanying text; see also infra notes 225-28 and accompanying text.

${ }^{211}$ The combination of contribution and expenditure limitations with limitations on candidate spending out of personal funds would have prevented a candidate or a candidate's supporters from circumventing any one limitation. Buckley v. Valeo, 424 U.S. 1, 260-61 (White, J., concurring in part and dissenting in part). The content-neutrality of the restrictions was conceded by the Court. Id. at 17, 39.

212 See supra note 137.
} 
attempt to draft a more narrowly drawn statute.

\section{Application of the Balancing Test to Democratic Party $v$. NCPAC}

Democratic Party v. National Conservative Political Action Committee ("NCPAC"), ${ }^{213}$ a case currently pending before the Supreme Court, involves many of the same issues raised in Buckley, and offers the Court an ideal opportunity to adopt and apply the proposed balancing test. NCPAC concerns the constitutionality of 26 U.S.C. $\S 9012(\mathrm{f})$, a section of the Revenue Act of $1971^{214}$ that provides in part for the establishment of a fund for public financing of presidential elections. Section 9012 (f) calls for criminal sanctions to be invoked against unauthorized political committees ${ }^{215}$ that spend over $\$ 1000$ to further the election of presidential candidates who have chosen to accept public funds for their election campaigns. ${ }^{218}$ This provision thus parallels the limit on independent expenditures created by FECA and struck down in Buckley, ${ }^{217}$ section $9012(f)$ applying where presidential candidates elect public funding. ${ }^{218}$

In NCPAC, the District Court for the Eastern District of Pennsylvania held that section 9012 (f) was unconstitutional under Buckley. ${ }^{219}$ The court focused only on the question of whether independent expenditures by unauthorized political committees could corrupt or appear to corrupt elected officials ${ }^{220}$ - the only consideration, according to the court's reading of Buckley, that

213578 F. Supp. 797 (E.D. Pa. 1983) (three-judge panel) cert. granted, 52 U.S.L.W. 3745 (U.S. April 17, 1984).

214 Pub. L. No. 92-178, § 801, 85 Stat. 497, 562 (1971).

218 The Act distinguishes two types of political committees. Authorized committees are those designated by a candidate as acting on his behalf, 26 U.S.C. $\$ 9002(1)$ (1982), and are subject to the Act's limitations regarding contributions and expenditures, id. $\S 9012$. All other committees are unauthorized and subject to the sanctions imposed by $\S 9012(f)$.

210 26 U.S.C. \& $9012(f)(1)(1982)$ provides:

[I]t shall be unlawful for any political committee which is not an authorized committee with respect to the eligible candidates of a political party for President and Vice President in a presidential election knowingly and willfully to incur expenditures to further the election of such candidates . . . in an aggregate amount exceeding $\$ 1,000$.

117 See supra notes 124-55 and accompanying text.

21826 U.S.C. $\$ 9012(f)$.

${ }^{219} 578$ F. Supp. at 816-39. NCPAC was not the first case to address § 9012(f). A threejudge court in the District of Columbia District had previously struck down $\S 9012(f)$ in Common Cause v. Schmitt, 512 F. Supp. 489 (D.D.C. 1980), aff'd by an equally divided Court, 455 U.S. 129 (1982). The Supreme Court heard the case on appeal, but divided equally and affirmed without issuing an opinion. 455 U.S. 129 (1982). The three-judge court in NCPAC therefore felt itself free to consider the statute anew. 578 F. Supp. at 801.

220 Id. at $822-31$. 
could justify the abridgement of protected speech involved.221 The court found that the limited possibility of corruption under the circumstances did not justify the broad scope of section 9012(f), which it therefore found unconstitutional. ${ }^{222}$

In order for the Supreme Court to apply the balancing test suggested here, it would have to look beyond the anti-corruption purposes of section $9012(f)^{228}$ and consider the extent to which the statute fosters rational election outcomes. First, the Court should look to congressional intent. Congress was concerned with the rationality of electoral outcomes when it considered the issue of public financing of elections. In the session of Congress prior to the one in which section 9012(f) was enacted, a public election financing bill ${ }^{224}$ was introduced to prevent money from becoming so influential in political campaigns as to distort the expression of the electoral will. ${ }^{225}$ In the ninety-second Congress, election law reform

321 Id. at 818.

223 Id. at 837-39.

${ }^{223}$ The statement in NCPAC that "the prevention of corruption and its appearance provide the only legitimate basis for regulating speech resulting from campaign finance," $i d$. at 818, reflects a misreading of Buckley. See also Common Cause v. Schmitt, 512 F. Supp. 489, 494 (D.D.C. 1980) (3-judge court) ("[T]he Court has indicated the prevention of corruption is the singular compelling governmental interest justifying the limit on maximum contributions to candidates."), aff'd without opinion by an equally divided Court, 455 U.S. 129 (1982). The proper reading of Buckley is only that, of the government interests cited by the parties, the prevention of corruption was the only interest found to justify the speech restrictions at issue. The Court did not hold that corruption is the only governmental interest that can ever justify such a restriction. The government interest in voter rationality was not expressly presented to the Buckley Court. See supra note 144 and accompanying text.

s24 Election Financing and Reform Act, S. 3659, 91st Cong., 2d Sess. (1970).

${ }^{286} 116$ CoNG. Rec. 9940-41 (1970) (Sen. Gore):

[A]n election ought to be a time of serious discussion, a time when ideas are brought forth and debated-not for the sound they make but for their meaning, not for their marketability but their merit, not for their packaging but their content. Because the most vital single action of a self-governing society is the election of public officials.

Unless the will of the people can be determined and maintained in elections there can be no government of, by, and for the people. Unless the elective process is surrounded by effective safeguards, there can be no real assurance that the will of the electorate will emerge.

[W] have a long way to go yet to make our voting system as free and unhampered and as equitable as all of us would wish it to be and to free it from the undue influence of money which is now throttling it....

The cost of campaigns has mushroomed, the practices of vested interests have become a threat to popular government, the influence of TV and other expanding communications media-and the advertising industry-has skyrocketed and there is now widespread and justifiable public concern over the threat to popular government arising from the improper influence of money in elections ....

The concentration of dollars poured out at election times serves to thwart the will of the American people both directly and subtly. Not many people would sell their 
was divided between FECA and the bill containing provisions regarding public financing of presidential elections. ${ }^{226}$ The two bills were meant to complement each other ${ }^{227}$ in an overall scheme to assure that "the merit of the candidate and not the amount of his resources will be the sole criteria [sic] of his fitness for public office."228

Public financing of campaigns was designed to promote electoral rationality by assuring that each major-party candidate ${ }^{228}$ spent the same amount of money in the general election campaign. ${ }^{230}$ Each candidate would have enough money to reach voters with his message, ${ }^{231}$ but no candidate would have the ability vastly to outspend his opponent. 232 This scheme necessitated limiting the amount of money a candidate could receive from sources other than the public financing fund ${ }^{23 s}$ to prevent public funding from

votes directly, but the influence exerted by merchandising and image-making does not come directly, and in this new form no one is immune to it-either in the purchase of soapflakes or in the choice of candidates for high office.

Simply stated, money can and does buy, in an effective sense, many elections without in any way violating our archaic elections laws and without buying a single vote. What is acquired by mass, and frequently misleading, propaganda is a favorable voter inclination based upon false or artificial premises.

${ }^{228}$ Revenue Act of 1971, H.R. 10,947, 92d Cong., 1st Sess. (1971). This bill originated in the House as a general tax and economic measure. In the Senate, it was amended on the floor to provide for public financing of presidential elections. 117 CoNG. REc. 19,308-09 (daily ed. Nov. 22, 1971). The amendment was agreed to, with minor changes, by the conference committee. See H.R. REP. No. 708, 92d Cong., 1st Sess. (1971); S. RRP. No. 553, 92d Cong., 1st Sess. (1971). As a result, the House never debated the election financing provisions of the bill.

${ }^{227} 117$ Cong. Rec. 18,879 (daily ed. Nov. 17, 1971) (statement of Sen. Pastore, sponsor of amendment).

${ }^{228}$ Id.; see also id. at 18,885 (statement of Sen. Bentsen) ("Wealth must not be allowed to become the yardstick for political talent . . . . The people . . . should be permitted a free choice of men and ideologies and ideas.").

229 Minor-party candidates and other candidates receive less than major-party candidates under the Act. 26 U.S.C. § 9004(a) (1982).

2so Currently, major-party candidates are eligible to spend $\$ 20$ million in the general election campaign. 26 U.S.C. $\$ 9004(a)(1)$ (1982); 2 U.S.C. $\$ 441 a(b)(1)(B)$ (1982). Subsequent amendments extended public financing to include primary election campaigns as well. Pub. L. No. 93-443, §§ 403-08, 88 Stat. 1291 (1974) (codified at 26 U.S.C. $\$ 9008$ (1982)).

${ }^{231} 117$ Cong. REc. 18,947 (daily ed. Nov. 18, 1971) (statement of Sen. Pastore) ("[T]he candidate will have enough money to be exposed to public attention so that the public will know him, know the issues as the candidate sees and solves them on the same level as the next man who is competing for that office.").

2s2 See supra notes 137-43, 188-94 and accompanying text; see also 117 CoNG. REc. 19,130 (daily ed. Nov. 19, 1971) (statement of Sen. Pastore) ("The question is: How much money must be spent in order that the people of the United States will have the proper exposure to the candidates and the issues, so that they can make a valid judgment.").

${ }^{233} 117$ CoNG. REc. 19,151 (daily ed. Nov. 19, 1971) (statement of Sen. Taft) (purpose of 
becoming "simply an additional layer on top of the existing level of spending." "2s4 Section 9012(f) was thus integral to the congressional scheme of public financing of elections, and, in turn, achieving more rational electoral outcomes.

After reviewing the congressional purpose behind the statute, the Court should balance interests in a manner similar to that which this comment has suggested as a proper approach to considering the constitutionality of FECA itself. ${ }^{235}$ Two issues peculiar to section 9012(f) are worth noting. First, the section may be overbroad. Independent expenditures exceeding $\$ 1000$ on behalf of candidates may in fact be insignificant compared to the amount of public funds provided directly to each candidate. Moreover, the disparity in spending among candidates might not be greatly affected by expenditures of amounts not greatly exceeding $\$ 1000$. Second, section 9012(f) limits expenditures by political committees but not by individuals or other groups. ${ }^{236}$ Therefore, the restriction might have a content-differential effect if it happens that political committees tend to support candidates of a particular type or party more frequently than do other groups or individuals. Furthermore, the marginal loss of speech from restricting political committees might be greater than that from restricting individuals because, as the NCPAC court noted, political committees amplify and make more effective the speech of many individual small contributors. ${ }^{237}$

If the Court undertakes the analysis suggested in this comment but nevertheless finds that, due to overbreadth or contentdifferential effect, section $9012(f)$ is unconstitutional, Congress could easily redraft the measure to eliminate these defects and render the statute constitutional. Thus, even a decision striking

$\$ 9012$ (f) was to place a "limitation of $\$ 20$ million . . . on expenditures on behalf of a particular political candidate" (emphasis added)); id. at 19,302 (daily ed. Nov. 22, 1971) (statement of Sen. Miller) ("[The] candidate is going to have to make up his mind; if he wants to get his financing out of the fund, then he cannot get a nickel anywhere else.").

236 Id. at 18,895 (daily ed. Nov. 17, 1971) (statement of Sen. Kennedy).

225 See supra notes 209-12 and accompanying text.

238 An amendment to extend the $\$ 1000$ limit on political committees to "any corporation, labor organization, partnership, association, political committee, political education committee or any other committee," was offered on the Senate floor by Senator Taft, 117 Cong. Rec. 19,151 (daily ed. Nov. 19, 1971), but was rejected. Id. at 19,156. Senator Miller successfully introduced an amendment on the Senate fioor to extend the $\$ 1000$ limit to individuals, id. at S. 19,302 (daily ed. Nov. 22, 1971), but this change was deleted by the conference committee. S. RkP. No. 553, 92d Cong., 1st Sess. 58 (1971).

${ }^{237}$ NCPAC, 578 F. Supp. at 819; see also Common Cause v. Schmitt, 512 F. Supp. 489, 497-98. (D.D.C. 1980) (3-judge panel), aff'd by an equally divided Court, 455 U.S. 129 (1982). 
down the section after a thoughtful balancing would be far preferable from the standpoint of electoral rationality than a flat constitutional prohibition of limits on independent expenditures.

\section{Conclusion}

If the purposes for which the United States government was formed $^{238}$ are to be realized through a democratic system of selfrule, it is essential that elections reflect, as nearly as possible, the rational choices of the people. While freedom of speech is surely a most important constitutionally guaranteed right, to place freedom of speech above the rationality of government itself is to ignore the fact that only through intelligent self-government are any freedoms, including freedom of speech, secured. ${ }^{239}$ In today's mediaoriented society, decisions such as Buckley v. Valeo that prohibit limits on runaway campaign expenditures open the door to individuals with the resources to acquire or maintain power by manipulating voters. ${ }^{240}$

The Supreme Court should reevaluate its interpretation of the first amendment in the election law area in order to allow the federal and state governments to confront the reality of irrational voting. The Court should recognize in its constitutional jurisprudence the need for a balance between freedom of speech and the pursuit of rational electoral outcomes. With such a recognition there would be no absolute bar to legislation designed to protect citizens from distortions of the democratic process worked by individuals with the desire and money to gain office through deception and exploitation of the electorate.

James A. Gardner

${ }^{238}$ See supra notes 18-22 and accompanying text. See generally U.S. ConsT. preamble; The Declaration of Independence para. 2 (U.S. 1776).

${ }^{230}$ See Reynolds v. Sims, 377 U.S. 533, 562 (1964); Wesberry v. Sanders, 376 U.S. 1, 17 (1964); Yick Wo v. Hopkins, 118 U.S. 356, 370 (1886) (all noting fundamentality of right to vote as guarantor of other rights).

240 "Let a prince, then, conquer and maintain the state; his methods will always be judged honorable and they will be praised by all; because the ordinary people are always taken by the appearance and the outcome of a thing; and in the world there is nothing but ordinary people." N. Machiavelu, The Prince 149 (1964) (1st ed. n.p. 1532). 